\title{
QUAL O TRATAMENTO PARA O SUJEITO AUTISTA?*
}

\author{
HOW TO TREAT THE AUTISTIC SUBJECT?
}

\author{
Jean-Claude Maleval, da Université Rennes II ${ }^{* *}$
}

\begin{abstract}
RESUMO
Para se construir, o autista, que recusa introduzir-se na alienação, é confrontado com uma dificuldade que pertence apenas à sua estrutura subjetiva: como tratar o gozo do vivo quando não se dispõe deste aparelho para mortificá-lo que o significante constitui? A esse respeito, os raros testemunhos de autistas de alto funcionamento que se engajaram no tratamento individual nos ensinam muito: eles podem ser encarados como um tipo de laboratório de estudo do seu funcionamento subjetivo. Sabe-se que a opinião dominante preconiza que se deve educá-los paparicando. Porém, não há justamente prática educativa que possa fazer a reserva de recorrer de maneira mais ou menos explícita à utilização do binário recompensa-punição. Que o autista tenha ciência desse binário, isso é um postulado que não é interrogado por quem deixa de lado a teoria do sujeito.
\end{abstract}

Palavras-chave: Autismo. Alienação. Testemunho. Práticas educativas.

"Se eles não chegam a escutar o que vocês têm a lhes dizer", afirmava Lacan a propósito dos sujeitos autistas, "é por conta de vocês estarem preocupados com isso." (LACAN, 1985, p.21). Ninguém duvida, com efeito, que um querer [vouloir] demasiadamente afirmado no que diz respeito a eles acentua o seu retraimento. Logo de início, Asperger já havia observado que, para ser ouvido por eles, mais valia não se preocupar demais com isso: ele aconselhava falar "sem se aproximar deles pessoalmente", com calma e sem emoção, "fingindo uma paixão desbotada." (ASPERGER, 1998, p.69).

Contudo, a tendência do educador não é de se apagar: ele tem posse de um saber suposto a fazer o bem para o sujeito. Geralmente ele dispõe, no que concerne aos autistas, de uma teoria dos estádios de desenvolvimento aos quais ansiaria fazer com que a criança ascendesse. Talvez seja uma teoria do simbolismo aquilo que o incita a privá-la de seus objetos autísticos; ou, ainda, aquilo que o orienta talvez seja simplesmente uma idéia de normalidade. Essa última leva a admirável Mira Rothenberg ${ }^{1}$, por exemplo, a se preocupar demasiadamente com Peter, na melhor das intenções, fazendo o que constitui, sem dúvida, o pior dos erros que um terapeuta de autista possa vir a cometer, a saber: pedir com insistência que ele tome uma posição de enunciação.

'Durante semanas", relata ela, "corrigi sua expressão oral, pedindo que pusesse um pouco mais de energia na voz - para ser vivaz [vivant] quando estiver falando, explicava eu". Ela constata que ele "permanecia surdo" ao seu conselho. Insistia, então, em tentar a mesma técnica com a leitura: pedia que lesse de uma forma vivaz. Alguma coisa nas minhas palavras deve tê-lo tocado", relata ela. "Levei um pontapé nas

\footnotetext{
* Artigo recebido em 20/02/2009 e aprovado em 21/08/2009.

** Tradução de Paulo Sérgio de Souza Jr., a partir do texto «Quel traitement pour le sujet autiste?" publicado em ORNICAR? Digital Nova Época, n. 307; setembro, 2007.
} 
canelas". Entretanto ela não se desencorajou; e Peter, irritado, começou a ler "tal como batia - com energia e vitalidade". Uma leitura assim não implica necessariamente o fato de ele ter engajado aí sua presença enunciativa - além do mais, não é uma expressão do seu próprio sentimento [ressenti] -, mas, sim, que ele percebe que era isso que não parava de lhe ser pedido. Ele fez esforços para satisfazer sua terapeuta.

Um dia, relata ela, leu-me uma história com uma força e uma animação que raramente havia visto nele antes. Eu exclamava:

- Formidável! Era isso que eu estava querendo dizer.

De repente ele voltou seus olhos para os meus aterrorizado. Siderada pela expressão que eu lia em sua face, balbuciei:

- O que foi, Peter?

Ele urrou:

- Porque depois tem o cemitério!

- Depois do quê?

— Quando você está bem. Então, depois, há um beco sem saída e um cemitério.

Mira Rothenberg interpreta com pertinência essa última frase, supondo que ele queria dizer "que depois de se ter conhecido a vida, deve-se morrer." Dar vida à linguagem é, para o autista, pôr-se a escutar o objeto angustiante do gozo vocal; mas está no princípio de sua estrutura subjetiva que ele não seja mortificado pelo significante, de tal modo que nada teria como ser mais angustiante para ele. A seqüência desse fragmento clínico exemplar confirma isso. Ela lhe comunicou o que havia compreendido da relação que ele estabelecia entre a vida e a morte. "Ele começou a tremer e a transpirar. Então correu para a janela, ficou totalmente mudo, retraído como se estivesse murchando e começou a contar [compter] - o que há muito tempo não fazia". Sublinhemos o retorno do retraimento e de um mecanismo de proteção abandonado, o que testemunha fortemente a ressonância subjetiva do incidente. Evidentemente ele não persiste em seus esforços para mobilizar a enunciação: "inútil dizer", comenta Rothenberg, "que seu modo de falar e de ler voltou mais monótono do que nunca."

"Depois desse episódio", prossegue ela, "Peter tentou me evitar. Disse para sua mãe que não queria que [eu] falasse [com ele]. [...] Para mim dizia: 'Peter não quer que você vá com ele ao Dr. Goldstein'. Quando eu lhe perguntava o motivo, me respondia somente: 'Porque Mira dirá ao Dr. Goldstein'. Eu interrogava: Dizer o que?; ele replicava invariavelmente: 'Porque Mira sabe', ou então 'A verdade'". Não teria ela se aproximado, com efeito, do mais próximo possível da verdade do autista, uma vez que não hesitou em lhe formular que sua angústia tinha origem na expressão do vivo?

O incidente da leitura teve uma profunda repercussão na sua relação. "Ele criou uma fissura entre nós", relata Rothenberg, que a essa altura trabalhava com Peter já havia três anos, de tal modo que "demos, assim, marcha-ré durante mais ou menos seis meses". Ela tentou interpretar o que se passava, dizendo "que fingia estar morto porque, talvez, tivesse verdadeiramente medo de morrer caso começasse a viver. Peter se afastou, então, de mim", relata ela, "e tentou freqüentemente me fazer mal fisicamente, pois", dizia ele, "Mira conhece a verdade"”. Em seguida, Rothenberg se sentiu um pouco "assustada com seu furor contra ela"; e imaginou, ainda que de forma confusa, que devia de ter cometido um erro - não escondendo que "se sentia muito culpada por sua atitude", de tal modo que, durante os seis meses de frieza, tentou desesperadamente reatar o contato. 
Esse fragmento clínico mostra que a devoção não basta para trabalhar com um sujeito autista, e que uma prática esclarecida pela abordagem psicanalítica permitiria orientar-se melhor. Entretanto, sabe-se que a opinião dominante preconiza que se deve educá-los paparicando. Porém, não há justamente prática educativa que possa fazer a reserva de recorrer de maneira mais ou menos explícita à utilização do binário recompensa-punição. Que o autista tenha ciência desse binário, isso é um postulado que não é interrogado por quem deixa de lado a teoria do sujeito; contudo, mesmo nos autistas verborrágicos, a aquisição do sentido do som se dá com dificuldade. Disso resulta que muitos vivem as punições como incompreensíveis; logo, injustificadas. Williams sabe melhor do que ninguém já que teve muito freqüentemente a experiência de que "o princípio da disciplina', constata ela, "comete o erro grosseiro de supor que o culpado se pergunta o porquê.” (WILLIAMS, 1996, p.41). Ora, para ela, em sua infância,

as punições não significavam nada. Elas não tinham qualquer ligação lógica com as ações que eram supostas a repreender. Eu ignorava totalmente o que tinha feito. $\mathrm{Ou}$ melhor, tentava compreender com o que é que se pareceria uma "garota bemcomportada" para, então, poder imitá-la.

Muitas técnicas comportamentais, como nota Schopler, são empregadas espontaneamente pelos pais e educadores - em particular as reprimendas e o reforço positivo (SCHOPLER; REICHLER; LANSING, 2002, p. 122). Quando se pergunta a um autista de alto funcionamento, como Sean Barron ${ }^{2}$, se ele pensa que esse método de gestão do comportamento teria podido ajudá-lo quando criança, recompensando as boas condutas e punindo as más, depois de ter lido as explicações do método, ele confirma o testemunho de Williams: "não vejo como teria podido funcionar. Eu estava pouco me lixando para recompensas e punições. Na realidade, eu não tinha vontade de nada, nem de coisas de comer; então, do que é que teriam podido me privar?" (BARRON e BARRON, 1993, p.315)

Por volta de cinco anos, Barron tinha uma regra, expressão subjetiva disso que é descrito como imutabilidade: não devia tomar água nos restaurantes. Deviam lhe servir bebidas das quais ele gostasse, como Coca-Cola - caso contrário, entrava numa cólera terrível. Seus familiares [proches] não entendiam porque os copos d'água faziam-no urrar. Um terapeuta - não tendo recebendo resposta alguma, quando perguntou por que é que ele havia feito aquilo - decidiu dar-lhe uma sova. "Jamais pensei que ele poderia me bater", lembra-se Barron.

Nem cheguei a acreditar! É porque sou mau - pensava eu então. Papai e mamãe me batem, e agora também esse homem bizarro. Não via o que eu podia ter feito para que me batesse [...] Entretanto, ele tinha me punido por alguma coisa. A partir desse dia foi como se ele não existisse mais. Podia dizer o que fosse, eu me recusava a compreender. (BARRON e BARRON, 1993, p.91).

Ainda que tenha compreendido mal o sentido das palavras endereçadas a ele, a noção de punição vem dos golpes e da entonação enfurecida, mas permanece sem relação com seus atos; ele depreende disso apenas a sua maldade.

Outros autistas, tais como Grandin ${ }^{3}$ ou Sellin ${ }^{4}$, chegam a compreender desde a primeira infância o que lhes dizem, mas não podem responder, ainda que às vezes pronunciem algumas palavras. Não é fácil apreender - pelos métodos que, em nome da 
ciência, entendem não precisar de uma teoria do sujeito - que se trate de um impedimento ancorado no funcionamento subjetivo, e não numa má vontade.

Muitas crianças autistas mostram-se hipersensíveis à menor das críticas de suas tentativas de aprendizagem, vividas como desencorajadoras e maldosas, pois não as compreendem. Na falta de poder simbolizá-las, elas vêm ao seu encontro como manifestação do gozo do Outro. As crianças sofrem, então, com o fato de serem designadas como seres maus - o que podem vir a ser, de fato, em momentos de violência, quando suas defesas não são respeitadas.

Por outro lado, o homem normal, no horizonte de todas as abordagens educativas, incita considerar como uma evidência que, para ajudar o autista, convém "tratar o apego não-adaptado aos objetos ou a adesão inflexível às rotinas quotidianas" (HEMSLEY et al., 1991, p.479). Uma abordagem orientada pela psicanálise leva a desconfiar desses pressupostos - antes de mais nada, por razões éticas; mas também porque eles não levam em conta o trabalho de proteção contra a angústia em operação nessas condutas.

Os trabalhos sobre a especificidade da sua inteligência - que comandam a maioria das estratégias educativas propostas para os autistas - são acompanhados, de modo geral, por um desconhecimento do funcionamento subjetivo. A maneira pela qual o binário recompensa-punição é recebido praticamente não é interrogada; a angústia inerente à enunciação não é levada em conta; a função de contenção do gozo própria dos objetos autísticos e do trabalho de imutabilidade é ignorada; a maneira bem particular pela qual o sujeito autístico se constrói não é sequer imaginada.

Por essas razões, e algumas outras, o tratamento psicanalítico do autista e a reeducação de sua deficiência [handicap] não se mostram compatíveis. Contudo, a criança autista não é um sujeito em condições de fazer uma demanda de análise. Acontece de ela se engajar num tratamento por conta da demanda de seus pais, contanto que ela tenha uma boa impressão [rencontre]; isso continua raro, e não dispensa que procurem para ela um ambiente apropriado a suas dificuldades específicas. Alguns pais chegam a criar um ambiente assim ao preço de sacrifícios consideráveis e de uma devoção sem limites. A abnegação de uma Clara Park (1972), de uma Judy Barron ou de uma Tamara Morar (2004) compelem à admiração. Aconteceu-me de encontrar anônimos que não fazem por menos. Consagrar-se a tirar seu filho do retraimento autístico se paga, contudo, com um pesado tributo no que diz respeito à vida social e profissional, de tal modo que tais práticas só podem continuar sendo excepcionais.

O tratamento mais apropriado com crianças autistas consiste, portanto, em procurar instituições advertidas de seu funcionamento subjetivo e organizadas em função dele. É o projeto que rege aquelas que se referem a uma variante da psicanálise aplicada nomeada por Jacques-Alain Miller como «la pratique à plusieurs» ${ }^{5}$ (DI CIACCIA, 2005, p.107-8). Ela implica que seja preservado um vazio central de saber, a fim de que a teoria da clínica não seja estancada e que a singularidade de cada criança possa contestá-la. Nesses lugares, as invenções do sujeito são acolhidas sem que sejam submetidas ao standard de um suposto conhecimento das etapas de um desenvolvimento típico.

\section{A CURA FREUDIANA COM MARY: ILUSTRAÇÃO DA VERDADE}

Para se construir, o autista, que recusa introduzir-se na alienação, é confrontado com uma dificuldade que pertence apenas à sua estrutura subjetiva: como tratar o gozo 
do vivo quando não se dispõe deste aparelho para mortificá-lo que o significante constitui? A esse respeito, os raros testemunhos de autistas de alto funcionamento que se engajaram no tratamento individual nos ensinam muito: eles podem ser encarados como um tipo de laboratório de estudo do seu funcionamento subjetivo.

Dos 17 aos 19 anos, na Austrália, Donna Williams consultou regularmente uma psiquiatra cuja prática era orientada pela psicanálise, e que soube ganhar sua confiança. Esse contato foi importante: ela exerceu uma influência sobre sua "vida mental como ninguém, desde Carol, jamais havia feito" (WILLIAMS, 1996, p.163). Essa última, uma garota encontrada uma única vez, por volta da idade de cinco anos, foi o espelho no qual ela achou o alicerce de um de seus dois amigos imaginários - que nomeou Carol, justamente. Graças a ela, criou para si

um eu [moi] diferente daquele que estava paralisado e entravado pelas emoções. Isso virou mais que um jogo, mais que uma comédia. Era minha vida, na qual devia eliminar o que aparentava emoções pessoais e, ao mesmo tempo, fazer Donna desaparecer (WILLIAMS, 1992, p.42)

A terapia com Mary inscreveu-se nessa filiação: ela se tornou o suporte de um novo duplo. Ela foi, escreve Williams, "o reflexo mais bem adaptado, mais cordial que eu jamais teria vindo a ser". Um duplo encarnado, tanto que Mary apresenta a vantagem sobre os amigos imaginários - Carol e Willie - de poder produzir efeitos de sugestão. Ela não falhava [n'y manqua pas], de tal modo que Williams tirou alguns proveitos desse tratamento.

O comportamento de seus amigos imaginários, encarnados alternadamente em sua vida social, viu-se pacificado: "de carcereiro, Willie se tornou psi. De menina de rua, Carol se tornou uma mulher elegante". Além disso, Mary lhe ensinou "descomunalmente a agir e a pensar como ela". Donna chegou mesmo a pensar em se tornar psiquiatra. Mary incitou-a a retomar os estudos, tanto que, no final do tratamento, para parecer com sua terapeuta, ela entrou na Universidade. Todavia, Williams considera que esse tratamento fracassou em modificar o seu funcionamento subjetivo: não a ajudou a "tornar-se 'real', ela continuou a fugir de seu eu" [moi], a "esconder-se por detrás de um psi" (WILLIAMS, 1996, p.55). Que Mary tenha acreditado na sua capacidade de seguir os estudos universitários permitiu que Donna acreditasse, e que os levasse a cabo, mas sobretudo pelo intermédio de encarnações de Willie - seu duplo que tinha senso de responsabilidade e era "um universitário nato" (WILLIAMS, 1992, p.196).

A tese segundo a qual a transferência do autista seria profundamente destrutiva não se deixa confirmar aqui. Williams aponta que tinha confiança em Mary porque ela "a tinha aceitado como ela era", não tentando reeducá-la, e porque era profundamente apegada a ela. No fim de dois anos, o tratamento consumou-se numa amizade recíproca. É preciso, sobretudo, sublinhar que ela buscou tornar sua ligação duradoura, integrando Mary ao seu próprio universo. Contudo, essa construção imaginária não se operou alcançando Donna, a integração se fez por intermédio de Willie: ele começou a se tornar, como Mary, "um artifício de força sereno e de domínio [maîtrise] de si." (WILLIAMS, 1992, p.189). Em poucas palavras, os efeitos desse tratamento de inspiração freudiana, efetuado frente a frente, por uma psiquiatra que parece tê-la considerado como esquizofrênica, foram os de uma psicoterapia de apoio. Educou as encarnações egóicas [moïques], particularmente Willie, num sentido satisfatório para Williams; só que ela esperava mais. O tratamento fracassou em modificar sua posição 
subjetiva, deixando-a em um funcionamento que implica o recurso a uma encarnação de seus duplos para se adaptar socialmente, o que ela vive como doloroso e mutilador.

Entretanto, ao incitar Williams a procurar a causa de seus problemas em sua história, Mary chegou a beirar o mais perto da verdade de Donna. Um traumatismo que ela situa por volta dos três anos de idade, quando acreditou que seu avô havia morrido. "Ainda me vejo", escreve ela, "procurando meu avô, em vão, com os olhos. Era nesse triste estado de nostalgia inacessível que me pus perto de sua cama, quando acreditei que estivesse morto. É o tipo de estado mental a que você se presta, quando um fantasma [fantôme] vem falar com você" (WILLIAMS, 1992, p.172). Esse traumatismo fundador ilustra [met en image] a perda de um ente querido, na qual o Outro ainda não morreu, mas é inatingível. O olhar de Donna se perde no vazio, como o apelo [appel] de Marie-Françoise na janela aberta (LEFORT: LEFORT, 1980, p.277) - para ambas, o Outro está ausente. A tentativa de reatar um laço com o Outro, operada por Donna Williams durante o tratamento com Mary, quando ela endereça a fala a um homem que considera ser seu "novo avô", reatualiza esse trauma específico.

"Bom dia, disse eu timidamente, em um esforço de sair de mim mesma" sublinhemos que aí é ela mesma, Donna, quem fala, e não um de seus duplos; ela tenta tomar, "timidamente", uma posição de enunciação. Mas o Outro não cessa de estar ausente. "Ele partiu sem dizer uma palavra". Segue-se imediatamente uma crise de angústia intensa. Ela desaparece, sua percepção se desestrutura, se atira na frente de um carro, procura refúgio junto a Mary num hospital psiquiátrico.

Mary procura analisar as razões de seu pânico perguntando em que é que o velho homem lhe tinha feito pensar. "Ela estava começando a ir longe demais", aponta Williams, que busca primeiramente minimizar o incidente, dizendo que tinha simplesmente se desiludido com a indiferença desse homem. A terapeuta insiste, quer remexer o seu passado. Williams comenta:

Ela se aproximou do fundo. Bem perto. Não, eu não podia, eu não queria me perder entregando-lhe a solução, o segredo de minha existência. Pois bem. Sim, ele tinha me lembrado meu avô. Estava dito. Donna foi traída, descoberta, e ela começou a soluçar. Seu choro era patético. Mas não se podia sequer consolá-la, ela recusava que a tocassem.

O avô foi a primeira pessoa que soube se fazer admitir no mundo de Donna; o primeiro objeto humano cuja perda lhe foi dilacerante. A emergência de uma fala de Donna, sem passar pelos duplos, suscitada pelas investigações de Mary, é dolorosa: ela rompe seu sistema de defesas, não alivia a angústia. A escrita em primeira pessoa, "ele tinha me lembrado meu avô", pula para a terceira pessoa, "Donna foi traída".

Contudo, essa última se protege mais ainda: não deixa Mary penetrar na verdade derradeira, aquela na qual a estrutura autística se enraíza; aquela que levou o sujeito a morrer para "o mundo". Ela continua:

Mary evocou comigo a morte de meu avô, sua morte efetiva. Eu me abstive de mencionar a verdadeira chave do enigma: ele tinha sido morto por mim bem antes, como todos os outros, quando Donna tinha três anos e quando Willie começou, com raiva, a olhar as pessoas direto nos olhos; e quando Carol tinha saído do espelho para acalmá-los. 
Williams situa retrospectivamente a emergência de seu funcionamento autístico por volta dos três anos - de fato, a emergência daquilo que ela pode conceber. Ela o situa no momento em que começou a construir seus duplos. Ora, ela correlaciona esse funcionamento à morte de seu avô, que, entretanto, ainda era vivo - ele só morreu dois anos mais tarde. A cena do avô sobre a cama ilustra sua relação com o Outro: ele se ausentou, mesmo que ainda estivesse vivo. O Outro do autista não está totalmente ausente: é, diz ela, um "fantasma". Imagem inquietante, feita justamente para encarnar o Outro real. Um fantasma que convém, sem dúvida, não acordar e correr o risco de encontrar. $\mathrm{O}$ autista não ignora que, para além dos duplos protetores, um Outro que goza [jouisseur] se sustenta. Um Outro que, como o próprio sujeito, não cede ao gozo.

Williams sublinha que seu olhar não vai mais de encontro ao do avô. Ela pode olhá-lo, mas não pode fazer-se ver: a pulsão escópica não tem a possibilidade de contornar um objeto situado no campo do Outro. Aí se esconde a verdade derradeira: que nada falta ao sujeito autista; que ele permanece intacto quanto ao gozo. O que Williams expressa nos seguintes termos: "é a esperança que havia matado Donna" - ou seja, sobretudo não esperar nada, pois é doloroso demais. Acrescenta: "Ela que não tinha nada, coisa alguma capaz de saciar [combler] seus desejos e suas imaginações". Todo objeto seria decepcionante, só um gozo infinito poderia satisfazê-la [satisfaire].

Quando seus duplos sobem à cena do mundo, Donna se faz ausente e os outros são correlativamente afastados a uma distância inatingível. "Todo mundo estava morto quando Donna desapareceu, escreve ela, mas ninguém havia notado. Muito pelo contrário, as pessoas que tinham contato com Carol ou Willie acreditavam que ela tinha, enfim, vindo à vida" (WILLIAMS, 1992, p. 175).

Um ponto que Williams não explicita permanece obscuro, verdade talvez ainda mais escondida, mesmo para o leitor de sua autobiografia: por que matou seu avô dois anos antes de sua morte? Ela relata ter sido confrontada a isto:

Um dia em que tinha acabado de encontrá-lo, escreve ela, ele não notou minha presença. Estava estendido no canto, o rosto marmoreado e arroxeado. Vovô não se levantou nunca mais. Eu nunca o perdoei, ao menos até meus vinte e um anos, quando descobri bruscamente que as pessoas não dão um jeito, intencionalmente, de morrer. Então chorei e chorei, cada dia mais. (WILLIAMS, 1992, p. 24).

Depreendemos, com isso, que ela ficou brava com a sua morte por ele ter morrido intencionalmente. Mas não é aí que está o essencial - podem admitir Mary e o leitor. Há pior: ela já o havia matado. Mas por quê? Porque anteriormente à morte real de seu avô situa-se a cena em que havia acreditado que ele estivesse morto. Dor dilacerante, abominável. Tanto que ela decidiu - sem sequer poder formular-se isso, sem dúvida - afastar-se de todo sentimento, a fim de nunca mais provar um sofrimento como aquele $^{6}$. Apareceu o que comanda seu funcionamento subjetivo: governar [maîtriser] totalmente as emoções, afastando-se delas. Ela escuta mais tarde, aliás, "uma voz interior", lembrando-a dessa "lei: [...] as emoções", diz ela, "são ilegais' (WILLIAMS, 1994/1996, p.46). Logo, o maior erro consiste em tornar-se vivo, isto é, em reatar o pensamento às emoções.

A criança autista não chora, às vezes não sente dor física, e considera os traços de afeição a seu respeito como sendo perigosos. "Era precisamente a violência de meus sentimentos", afirma Williams, "que me forçava sempre a me afastar daqueles que eu amava" (WILLIAMS, 1996, p.240). Da mesma forma, quando se submete a um ato sexual ou quando não pode impedir que a toquem, ela abandona seu corpo, afasta-se 
dele, sobretudo para não sentir nada. A clivagem a- $\mathrm{S}_{1}$, que caracteriza a estrutura autística, ancora-se num trabalho subjetivo de proteção contra a angústia. Com isso, como fortemente sublinharam os Lefort: nem lalíngua, nem $\mathrm{S}_{1}$ no autismo (LEFORT; LEFORT, 1998, p.37).

Mais vale matar o Outro por antecipação para não mais sofrer, revela Williams, ilustrando sua relação com o Outro real - que os Lefort souberam tão bem mostrar como fundamentalmente destrutiva. Para o azar do autista, o Outro real é incansável: o sujeito pode afastar-se do gozo do vivo, mas, a não ser que se suicide, ele persiste. "É absurdo", afirma Sellin, "pretender que não sintamos nada" (SELLIN, 1998, p.41); as emoções subsistem, mas sua interpretação não se faz, de tal modo que o gozo se mostra invasivo [envahisant] e incompreensível. O autista procura romper todo laço com o Outro real, presente no para-além de seu mundo seguro - no mundo dos seres vivos imprevisíveis e inquietantes. Seu gozo chega a seu pensamento de maneira caótica e inapreensível, do exterior de seu mundo, bem como do interior de seu ser.

A abertura excepcional produzida pelo tratamento de Williams leva a situar o enigma fundador da escolha do sujeito autista numa recusa da mortificação do gozo de seu ser, o que produz a "morte" deste e o afasta do Outro simbólico, na falta de poder angariar [prélever] de si a falta que dá ao desejo a sua dinâmica. O ser do autista não pode inicialmente entrar em ação [s'animer], a não ser protegido por detrás de seus duplos. O que Peter nomeia "a verdade", adivinhada por Rothenberg, não é de outra natureza que não a do segredo de Williams: Mira tinha compreendido, na presença da angústia desencadeada por uma leitura vivaz, que o ser de Peter não devia cessar de fingir-se de morto ${ }^{7}$.

"Meu eu [moi] real, esclarece Williams, "ainda estava se deixando hipnotizar pelas cores, enquanto Carol aprendia a dançar e Willie a lutar. O mesmo é dizer que eu estava morta para o mundo". A hipnose suscitada pelas cores é uma saturação do gozo escópico produzido pelos filamentos mágicos e estrelas percebidos ao se ajustar num primeiro plano, e que afasta do resto do mundo. Segundo seu testemunho, o ser do autista - o que ela nomeia como seu "eu real"- parece "auto-sensual". Todavia, apesar de sua morte imaginária, não deixa de conservar uma certa dinâmica: ele trabalha para manter a clivagem a- $S_{1}$, esforça-se para não se tornar "vivo". Para isso, o mundo interior seguro deve permanecer sob controle, totalmente dominado [maîtrisé], de tal modo que sua imutabilidade - estruturada por regras próprias ao sujeito - seja permanentemente preservada.

A esse respeito, Williams tem uma intuição de uma pertinência notável quando tenta diferenciar o autismo da esquizofrenia: num, discerne ela, trata-se de combater pela separação do intelecto e das emoções; ao passo que, no outro, as defesas se orientam contra. Ela sublinha fortemente essa oposição. Entretanto, num primeiro momento, parece ir contra o senso comum: Williams afirma que o sujeito autista é que está clivado, e não o esquizofrênico. Ora, trata-se justamente, no autismo infantil precoce, de um trabalho para manter a clivagem a- $\mathrm{S}_{1}$; ao passo que, na esquizofrenia, $\mathrm{o}$ sujeito tenta amarrar os $S_{1}$ pluralizados aos $S_{2}$.

Um tratamento freudiano pode, pois, conduzir a uma ilustração da verdade do sujeito autista, mas a brecha das defesas que produz, então, não somente não é de proveito algum, como também até mesmo arrisca desestabilizá-lo fortemente. Conduzir o tratamento rumo a um núcleo de verdade constitui uma prática perigosa, o que Williams percebe perfeitamente no só-depois: "quando a primeira psiquiatra me pediu 
para evocar minhas lembranças (e os freudianos têm tendência a adotar essa linha), sua pergunta me pareceu espantosa e perigosa." (WILLIAMS, 1996, p.73)

\section{O TRATO DO OUTRO COM O DR. MAREK}

Nove anos depois do término do tratamento com Mary, Williams se introduz em outro tratamento, conduzido de forma bem diferente. O doutor Theodore Marek não era «psi», segundo seus próprios dizeres, mas psicólogo escolar, possuindo uma longa experiência na prática com autistas. Ele tirou a conclusão de que sofriam de um mau processamento da informação, de tal modo que conduziu seu trabalho procurando retificá-lo.

Ele não parte do privilégio de uma relação dual, propícia a suscitar os jogos de espelho do duplo. Propõe para Williams, logo de saída, um objeto intermediário: uma bateria de testes. Ela aceita sem demasiada inquietação, e no final das provas lhe pede algo: que ele faça com que ela tome conhecimento do "que é que deu". E ele não dissimula seu saber: comunica a ela que, nos testes de inteligência, ela é excepcional em certos domínios, atrasada em outros - e que esses extremos são típicos dos autistas. Essas palavras têm para Williams um efeito de verdade: elas esclarecem uma parte de seu funcionamento.

Eu tinha a impressão de estar sendo uma cobaia, mas também estava me sentindo aliviada. Eu compreendia, enfim, porque ora me consideravam um gênio, ora me consideravam uma imbecil; de fato, eu era os dois. Esses resultados explicavam também a fabricação de Willie. (WILLIAMS, 1996, p.59)

Marek teve sucesso, assim, logo de início - aliviando-a e posicionando-se como sujeito de suposto saber sobre o autismo. Ele afirma poder ajudá-la, no entanto ela duvida disso em razão dos problemas de generalização que possui: quando aprende como agir numa determinada situação, é difícil transpor para outra aquilo que aprendeu. Aceita, contudo, encontrá-lo por volta de três semanas. Ela lhe endereça uma demanda, não para que reúna as peças de sua história, mas para que lhe dê "regras absolutas". O autista precisa de ajuda para tratar seu Outro caótico. É preciso ordem, um sistema, garantias - o que ele procura bem cedo em sua busca por imutabilidade. Williams escreve a Marek que gostaria que ele lhe expusesse se sabia de coisas que ela deveria aceitar "como imutáveis e invariáveis" e regras que, !uma vez estabelecidas, não podem ser quebradas", a não ser por novidades que suprimiriam as antigas. Ela procura construir com ele um Outro de síntese estável, organizado, tranqüilizante.

Parece-lhe claramente que Marek não está no mesmo lugar que Mary: ela própria formula que ele não é um espelho. Em que lugar situá-lo, então? Poderíamos supor que toma o lugar de um educador; Williams não vê assim: ele não põe em funcionamento um programa de reeducação. Ele não a julga: ela sublinha que ele não diz que suas palavras são insensatas, não fica repetindo que ela não fale vagamente, não a trata como "desacreditada". Ele opera de um jeito diferente: se ampara em sua perguntas, a escuta, regula-se ao seu ritmo.

O que é bom, ela lhe escreve, é que eu não tenho que responder Sim, sim, sim quando falo com você; pelo contrário, eu posso dizer desculpe, mas não estou entendendo ou Você poderia reformular? E, além disso, você não fala muito rápido, e sua voz e seu 
ritmo são bastante regulares (o que é menos problemático e permite que eu me concentre). (WILLIAMS, 1996, p. 92)

Com isso ele a tranqüiliza, porque ocupa o lugar que convém: o de um Outro atencioso, regrado, limitado e prevenido. Torna-se apto a "validar suas experiências", traz para ela "algumas respostas". Ela lhe dá confiança, ainda que encare com receio ter de se deixar "desarmar" se o trabalho prossegue, isto é, ter de abandonar certos mecanismos de defesa. Com efeito, Marek vai chegar a modificar seu funcionamento subjetivo e sua construção da realidade.

Como isso se dá? Duas intervenções maiores mostram-se decisivas. Williams se mostra profundamente abalada quando, em resposta à sua pergunta, ele lhe comunica uma regra absoluta: "para pensar ou sentir, uma coisa deve de ter um sistema nervoso". A descoberta é rude: desde a idade de 3 anos, Donna vive em um mundo onde as pessoas faleceram, onde foram reduzidas a coisas-objetos, portanto a pessoas-objetos isto é, a presenças afastadas, de segunda ordem, de pouco interesse, difíceis de circunscrever, às vezes utilizáveis -; em contrapartida, correlativamente, os objetivos de seu mundo familiar eram vivos, eles lhe traziam segurança e consolo, conheciam sua existência e lhe faziam companhia.

A formulação dessa regra "bombardeia seu mundo". Ela se sente atormentada por essa nova idéia de que "um objeto estava morto, sem conhecimento, sem sentimento, sem arbítrio". Anteriormente, ela vivia num mundo onde: "tudo tinha uma vontade, ainda que limitada. Fosse um objeto imóvel ou móvel, dependia mais de sua vontade de se mexer do que da decisão de uma pessoa de deslocá-los". A intervenção do Dr. Marek a mergulha em um "universo de cadáveres materiais", ele põe por terra seu animismo reconfortante, o que faz com que ela sinta sua solidão com acuidade, uma vez que seus objetos familiares não a protegiam mais desse sentimento.

A "nova lógica" é inquietante, mas, desde a publicação de seu livro, Donna decidiu não mais se mutilar, evitando recorrer a seus duplos e não querendo mais se refugiar em seu mundo. Nesse momento do tratamento [cure], ela recorre a um novo mecanismo de defesa, que não passa pelo duplo, mas por um trato [traitement] original de seu Outro de síntese. A dolorosa regra absoluta lhe foi comunicada em inglês - ela vive em um país, a Austrália, onde todos falam inglês -; decide, então, recriar uma distância entre seu mundo seguro e o dos outros, sempre inquietante, falando consigo em alemão. Ela até mesmo encara fazer um teste para poder ensinar em alemão, pois lhe seria bem mais fácil ensinar em uma língua que não é a sua, e que não é "uma expressão direta" de si mesma. (WILLIAMS, 1996, p. 102)

A nova lógica a coloca num estado lastimável, ela resiste: ainda lhe é muito difícil ser um ser vivo e falar autenticamente. Contudo, por conta de mudanças na maneira de reconhecer a cólera e na dificuldade de interpretar a entonação, ela pergunta ao Dr. Marek como é que os outros fazem para adquirir esse conhecimento. Em resposta, ele é levado a lhe comunicar uma segunda informação decisiva, que bagunça novamente a realidade de Donna, permitindo que situe melhor sua diferença com relação aos outros. "Ele me explicou, relata ela, que os outros utilizavam simultaneamente expressões pessoais e linguagem falada, sem análise consciente. Tive a impressão de consultar um gênio" (WILLIAMS, 1996, p.147).

Ainda que o trabalho tenha envolvido momentos difíceis, Donna constata que ele a ajuda a sentir uma melhor inserção, que pouco a pouco ela acompanha melhor as conversas, e que os outros lhe parecem mais presentes. Ela descobre, nesse período, que 
os momentos de "Grande Nada Negro" não são suscitados pela aproximação da morte como acreditou durante muito tempo, ou como pensava Peter, ao evocar "o cemitério" mas que surgem quando se aproxima de suas emoções. Ela percebe que o caos angustiante de seu gozo está ligado à sua incapacidade de apreendê-lo: "Qual, mas qual? Urrava em mim um impulso à deriva". Ela entrevê apenas a nomeação de suas emoções para regulá-las; os medicamentos, uma vez prescritos por Mary, não lhe "serviram de grande coisa [...]era só", escreve ela, "eu poder nomear esses monstros e atrelá-los, ligálos aos lugares, rostos e momentos de sua proveniência que eu seria livre." (WILLIAMS, 1996, p.143)

Seu universo de objetos jaz a seus pés; ela descobre que suas estratégias defensivas a separam do mundo e que é preciso fazer uma escolha: estar ou não nesse último. Ela experimenta confusamente que o tratamento a ajuda a rumar para uma interrogação; constata que sua escuta sensível vai melhorando, de modo que aproveita a ocasião em que os Miller a procuram - os proprietários benevolentes de seu apartamento - para intensificar o trabalho de regulação de seu Outro de síntese. Ela decide bater na porta deles, armada de lápis e papel, e pedir-lhes que "mostrem emoções."

Eles aceitam se dedicar dia após dia, enquanto prossegue o trabalho com o Dr. Marek, com o qual eles têm contato. Mobilizam esboços de emoções, desenhos, barras, escalas, linhas de conexão, caixas de diálogo etc. para tentar fazer com que ela adquira os conceitos "claros e etiquetados". Eles lhe serão, por fim, uma grande sustentação, passando longas noites definindo e ilustrando para ela "uma pletora de conceitos sociais e emocionais inapreensíveis de expectativas, de convenções e de regras" (WILLIAMS, 1996, p.228). Um trabalho como esse de trato do seu Outro de síntese - fundado não em experiências internas, mas essencialmente na aquisição de signos visuais, na definição de conceitos, e na assimilação de regras - confirma a intuição de Asperger segundo a qual os autistas "compreendem tudo pelo intelecto", e somente pelo intelecto.

O trabalho com os Miller e com o Dr. Marek teve fim em 1992, em razão da partida de Williams para a Inglaterra - primeiramente para divulgar seu primeiro livro; em seguida, para lá se instalar definitivamente. Ela decidiu prosseguir de maneira solitária quando, na Inglaterra, tomou a decisão de redigir um segundo livro. Ninguém duvida, com efeito, que seu trabalho de escrita participa, por um lado, de uma tentativa de "juntar as partes do quebra-cabeças" do seu Outro de síntese: ela revela que uma das motivações de sua primeira obra tinha sido o de reler sua vida, para compreender sua "coerência interna"; uma pesquisa para encadear "os elos do passado", a fim de construir sobre as fundações (WILLIAMS, 1992, p.275 e p.25).

Ela atesta que seu trabalho com o Dr. Marek foi mais proveitoso do que o efetuado com Mary. Notemos a maneira pela qual ela designa seus dois principais terapeutas: uma por seu nome (tornou-se uma amiga integrada ao seu mundo, um duplo suplementar); ao passo que o segundo é um especialista, cujo sobrenome é sempre precedido por seu título (ele pertence a outro mundo, àquele do qual ela se protegia e que, antes de ele lhe transmitir regras absolutas, parecia ser tão incompreensível).

Mary não a livrou de seus duplos mutiladores - mecanismos de proteção contra a angústia -, cujo recurso necessário era, para Donna, um sofrimento. O mérito principal dessa psicoterapia de apoio foi de incitá-la a fazer estudos universitários, nos quais ela encontrou um primeiro trato do seu Outro: "a universidade", escreve ela, "havia me dado uma coerência e me protegido do caos" (WILLIAMS, 1992, p.216). O Dr. Marek não está interessado em seus duplos, mas unicamente em seu processamento de informação; ele permitiu que ela adquirisse um saber regrado, permitindo que se 
movesse melhor em uma realidade menos imprevisível. Segundo os termos da própria Donna, ele a orientou "para além do espelho" (WILLIAMS, 1996, p.204).

Ela chega a obter um diploma que lhe dá a possibilidade de ensinar como educadora infantil [institutrice]. Sua posição se modificou: sua escuta capta melhor o sentido; seus duplos estão menos presentes; ela se esforça para não negar o que vem de seu corpo; prova certos sentimentos; desenvolve a faculdade de falar pessoalmente. Tenta não mais cindir seu mundo, "mantendo intacto o sentido de seu eu [moi] e de suas emoções", o que faz com que se aperceba do fato de que "toda pessoa - autista ou não, querendo ou não - $\underline{\text { existe }}^{8}$ sobre o mesmo pilar: a subjetividade" (WILLIAMS, 1996, p. 189).

Porém, esses esforços continuam difíceis e não atingem um sucesso pleno. Em certas situações angustiantes, um duplo pode retornar, a despeito de sua vontade; e agora é ainda pior provar momentos de perda dos sentidos quando a estruturação de sua percepção se desagrega. De fato, ela integrou estratégias do mundo que "ajudam-na a se ajudar" (WILLIAMS, 1996, p.119), expressão que denota a persistência de um funcionamento um tanto quanto fechado em si mesma. Ninguém duvida que o desvio para o Outro de que o circuito da pulsão necessita não está plenamente restaurado. Continua mais fácil falar do que se fazer escutar, mais fácil olhar do que se fazer ver. Ainda que ela descubra o sentimento amoroso, não entrevê mais do que uma relação "assexual platônica".

Não se duvida, contudo, que sua relação com o gozo se modificou: ela não está mais separada de seu corpo, e a realidade lhe parece menos caótica. Um laço emocional se tece, observa ela, "porque um sentido petulante trespassa" (WILLIAMS, 1996, p.171). A clínica não permite duvidar de que a estruturação do Outro de síntese acompanha regularmente um ganho no enlace do ser vivo ao pensamento. É o que constata, por exemplo, Tamara Morar, depois de um trabalho regular com seu filho autista, incidindo sobre "a representação mental de conceitos concretos» - parcialmente análogo ao do Dr. Marek. Todos esses exercícios que favorecem "a reconstrução mental" ajudam, "contra todas as expectativas", ela se admira, "também a restabelecer as emoções, a aprender sua linguagem e sua expressão, a desenvolver a consciência de seus próprios sentimentos etc.». Conclui: «na realidade, tudo está intrincadamente ligado." (MORAR, 2004, p.150)

Certamente, a estrutura do sujeito é uma amarração [nouage] de imaginário, real e simbólico, mas essa amarração nunca está mais distendida do que no sujeito autista. Verifica-se que um trato do Outro possui a aptidão de estreitá-la. Ele encontra, contudo, limites que atestam que em mesmo os autistas de alto funcionamento mais bem estabilizados não atam borromeanamente ${ }^{9}$ os elementos de sua estrutura subjetiva limites, na realidade, como veremos, de um tratamento que se limita a uma intervenção no Outro da síntese.

Desde os primeiros estudos sobre o autismo, Asperger (1998) havia apontado que os sujeitos autistas reagiam favoravelmente caso se lhes apresentassem "as ordens não como pessoais, mas como uma lei objetiva impessoal". A partir do momento em que a realidade está estruturada, ela lhes parece menos perigosa e mais habitável. Todos estão, como Williams, à espera de "regras absolutas". Intervenções orientadas nesse sentido mostram-se aptas a um trato do Outro, não mediado por interpretações, mas direto, pela admissão [adjonction] de estruturas e regularidades. Nada é recalcado [refoulé] no Outro de síntese do autista, que não dispõe da maquineta de cifrar o gozo que consiste o significante. Ele deve, então, contentar-se com os signos, mas seu caos - 
que nenhum significante mestre organiza - causa seu sofrimento. "Não é a complexidade de uma língua que cria problema para os autistas", explica K. Nazeer.

De fato, é provável que ela antes mesmo os ajude, na medida em que quanto mais complexa for, menos uma palavra corre o risco de ser polissêmica. Quanto mais regras e estruturas, menos um autista deve se debruçar sobre a sua intuição e sobre o contexto. (NAZEER, 2006, p. 26).

Ele esclarece que o ideal para eles seria "um sentido / uma palavra [mot]", isto é, uma língua totalmente feita de signos.

Como explicar que se possa chegar a modificar a economia de gozo subjetiva, tratando o Outro de um sujeito que não dispõe do significante? Parece que seja preciso concluir que a aprendizagem intelectual da conduta adequada, numa dada situação, mostra-se apta a fornecer ao sujeito um quadro de funcionamento que lhe permita canalizar o gozo nessas circunstâncias.

O autista é freqüentemente levado a fazer, ele próprio, um trato do Outro através do estabelecimento de conexões regradas e controláveis, daí a freqüência disso que se chama de seus «pontos [îlots] de competência», a propósito dos quais ele testemunha um conhecimento admirável de um campo circunscrito do saber. Ele pode, então, dirigir-se confiantemente aos outros para lhes expor seu domínio excepcional em tal ou tal domínio - chegando, freqüentemente, até mesmo a "enchê-los". O desenvolvimento solitário e hipertrófico de um desses domínios conduz, às vezes, à síndrome do autista-sábio, mas o ponto de competência é - assim como o duplo e o objeto - um dos "pseudópodos" esticados cuidadosamente em direção ao mundo, como se exprimia Kanner (1983, p.63), de tal modo que está freqüentemente na origem das aptidões profissionais dos autistas de alto funcionamento.

Aliás, numa prática em consultório privado com autistas de Asperger, constatei ser freqüentemente levado a intervir para sustentar e desenvolver seus pontos de competência, sem poder dizer muito das razões disso - se acaso foi apenas a sua escuta que me incitou a ir nesse sentido. O ensinamento extraído do testemunho de Donna Williams me explicita retrospectivamente a lógica. Saibamos que isso não é o suficiente, é preciso, sobretudo, obter deles - e a continuação dessas linhas demonstra isso bem - que uma insatisfação dinâmica resulta da tomada de consciência de sua diferença; é nela que se origina uma escolha subjetiva rumo à autonomia social.

Seria preciso esclarecer que, ainda que o tratamento do autista consista apenas em tratar seu Outro de síntese, tratar-se-ia de outra coisa que não de educação: não somente o binário recompensa-punição se faz ausente dessa prática; é necessário, além disso, que o sujeito consinta - mas isso demanda, sobretudo, estar prevenido do funcionamento subjetivo. É manifesto que o trato do Outro que goza [jouisseur] pela criança-autista não verbal demanda competências que ultrapassam o conhecimento das estruturas de linguagem e da realidade compartilhada. Além disso, Williams sublinha que não lhe parece possível ensinar a autistas tudo o que podem realizar, porque "o sentimento inspira a ação", ou porque "vocês podem captar a idéia de um sentimento, mas ele não vai se tornar seu por causa disso" (WILLIAMS, 1996, p.287). Iremos constatar, com efeito, que as modificações da posição subjetiva do autista implicam uma mobilização necessária de seu gozo.

\section{UM OBJETO NO ESPELHO}


Voltemos, agora, às coisas que Williams admite ter resguardado da "nova lógica material" introduzida pelo Dr. Marek: três objetos que permaneceriam fora dela. Três objetos que o simbólico não seria capaz de tragar. Assim como o Outro de síntese não parece chegar a uma regulação plenamente satisfatória do gozo, não teria ele sucesso em impor totalmente sua ordem ao imaginário? Quais são os objetos que ela tenta manter apartados da terrível regra segundo a qual, "para pensar ou para sentir, uma coisa deve de ter um sistema nervoso"? Quais são esses objetos que, apesar de tudo, deveriam conservar algo do gozo do vivo? Seus companheiros de viagem, "duas pelúcias batizadas Urso Orsi [Ours Orsi] e Cão Viajante [Chien Voyageur]", bem como essa coisa particularmente investida constituída por seu "reflexo" (WILLIAMS, 1996, p. 99).

Ela esclarece que o Urso Orsi nunca rugiu, e que o Cão Viajante nunca latiu: são objetos familiares, pelúcias com as quais ela fala. Não são duplos vivos: Willie e Carol, seus amigos imaginários, foram desintegrados (ou, talvez, se interroga ela, reintegrados?). Ela admitiu suas capacidades e voltou para essas duas pelúcias a afeição que antes lhes dedicava (WILLIAMS, 1996, p.119). Resta "seu reflexo", que ela percebe não como uma imagem, mas como um ser escópico. Em sua infância, quando nada a impelia a sair de seu mundo protegido, apenas um candidato lhe parecia aceitável para ajudá-la a abrir-se ao Outro mundo: seu reflexo, que ela tentava encontrar no mundo do espelho.

Eu o olhava nos olhos. Tentava tocar seus cabelos. Em seguida, falava com ele. Mas ele permanecia para todo o sempre do outro lado, e eu não podia penetrar lá. [...] A lógica dizia que meu reflexo não me acompanhava, mas a percepção desse outro eu vivo [mobil] desafiava a lógica. Os dois não se anulavam, e eu não podia reconciliá-los. (WILLIAMS, 1996, p.16 e 99)

Compreendamos bem: a lógica lhe diz que um reflexo não é um objeto - ela sabe que não é uma presença autêntica -, mas sua compreensão intelectual é impotente: alguma coisa transborda, de tal modo que lhe impõe perceber o fenômeno de uma outra forma - seu reflexo é um ser vivo. O trato do Outro fracassa, nesse ponto, em se sobrepor ao gozo. Williams é dividida entre seu intelecto, por um lado - que lhe assegura que o reflexo é uma luz refletida no espelho - e, por outro lado, seu gozo - que comanda sua percepção, subverte seu intelecto e confere vida à imagem.

A presença do vivo em sua imagem é uma constante dos espelhos de Williams. É possível, assim constataremos, distinguir três deles. Em cada um se mostram modificações discerníveis de sua posição subjetiva: elas são orientadas por uma lenta integração dos duplos.

No primeiro espelho a imagem de Carol habita o reflexo. "Derivada de uma criança que encontrei num parque', relata Williams, "Carol se via em meu reflexo" (WILLIAMS, 1996, p.18). Ela se sentia compreendida e segura em sua companhia, a tal ponto que procurava entrar no mundo do espelho para se juntar a ela, reiterando muitas vezes suas tentativas de atravessar o vidro. É por volta da idade de cinco anos, alguns meses depois do encontro, que Donna decidiu nomear-se interiormente como Carol.

Essa captura transitivista através de uma garotinha simpática que havia se interessado por ela pode produzir-se com outras pessoas. Na sua infância, quando seu irmãozinho Tom gritava e chorava, "era o seu rosto", escreve ela, "meu próprio espelho, que havia gritado; eu mesma, portanto". Ela tentava protegê-lo colocando as mãos sobre a boca e o braço sobre os ouvidos, a fim de que não gritasse mais; sentia nas mãos, 
então, suas lágrimas e seu nariz escorrendo. "Meus olhos", aponta ela, "permaneciam secos, pois era ele que estava se encarregando de sentir minhas emoções; ele que tinha a benevolência de expressá-las em meu lugar." (WILLIAMS, 1992, p. 67).

O gozo do sujeito descarregado [rejeté] no espelho é uma constante do autismo, tão freqüentemente observada na cena da criança que pega a mão do adulto para fazer com que efetue uma ação manifesta - quando a escrita no computador não é possível ao autista senão em contato com o "facilitador"; discernível, também, quando o sujeito anima-se se agarrando a um objeto autístico, do qual Tustin havia notado que participava do duplo. Com isso, se se entende por borda autística um espelho plano que protege o sujeito do gozo do Outro ${ }^{10}$, a fórmula de Eric Laurent, segundo a qual no autismo o gozo retorna sobre uma borda ${ }^{11}$, circunscreve notavelmente um elemento essencial da estrutura autística. Ela a diferencia da síndrome esquizofrênica (em que o gozo retorna no corpo) e da síndrome paranóica (em que ele retorna no Outro).

No primeiro espelho de Williams. os duplos estão acondicionados: por detrás da imagem de Carol, esconde-se uma representação simbólica de Donna - um duplo não humano, um gatinho perdido, que representa, diz ela, seu "eu [moi] indefeso" (WILLIAMS, 1992, p.261).

O duplo animal ou mecânico ilustra uma posição subjetiva na qual o autista permanece fechado num mundo onde os outros têm pouco lugar, e no qual ele se vê frágil. Peter passa vários anos de sua infância a se considerar um gatinho e a desenvolver um ponto de competência sobre seus animais. Ele experimentou, relata Rothenberg,

\begin{abstract}
uma necessidade irresistível de conhecer gatos, de vê-los, de carregá-los nos braços, de se comunicar com eles, de ele próprio se tornar um gato. Durante os quatro primeiros anos a partir de quando o conheci, prossegue ela, ele passava mais ou menos metade de seu tempo (tanto de noite, quanto de dia) à procura de seus animais; ele ficava muito excitado [...] Quando conseguia agarrar um, seu rosto ganhava uma expressão estranha, feito uma mistura de excitação, terror, prazer e cólera. Apertava bem forte o animal contra si, como se tivesse medo de que ele escapasse; teríamos dito que havia, enfim, encontrado algo que há muito tempo havia perdido, e que tudo o que queria era unir-se [faire un] a ele. Ao mesmo tempo, tínhamos a impressão de que queria destruí-lo e, talvez, fazer-se destruir por ele, deixar-se absorver, fundir-se nele.
\end{abstract}

O sujeito encontra-se numa relação de dependência com um duplo animal - ou mecânico - de modo que ele não é apenas uma proteção, mas também um objeto ameaçador, que vela a muito custo o Outro que goza [jouisseur]. Entretanto, antes que Rothenberg chegue a se fazer reconhecer como duplo, o gato tinha sido a única relação "segura", sem perigo, que Peter tinha conhecido; esse animal representava, escreve ela, "o intermediário garantido entre ele e o mundo que o cerca - a vida" (ROTHENBERG, 1979, p.265-267).

No que concerne a Williams, por detrás da imagem de Carol, só a do gato adquiriu a mesma consistência para Peter. Quando, num momento de angústia, Carol se apaga no espelho, "sua própria face" surge aterrorizada - a face de Donna, que perde o juízo, corta os pulsos (WILLIAMS, 1992, p.149). Seu outro duplo, Willie, intervém, então - mas este não é especular, é um garoto combativo, um manual escolar ambulante, mais ancorado no Outro de síntese do que na imagem. Quando nenhum duplo se interpõe entre o sujeito e o Outro, o ser de Williams se desvela, mas não um animal, e sim um "espectro, [...] um cadáver vivo." 
Mais tarde, retornando aos lugares de sua infância, ela encontra uma inscrição no muro de uma cabana, traçada quando tinha seis anos, numa época em que ainda não utilizava o "Eu" [je]: "Donna é maluca". Se o sujeito autista não chega a recorrer ao duplo para se proteger, fica na posição de objeto do gozo do Outro. Ele se vê, então, incitado a automutilar-se, a quebrar, a urrar; na melhor das hipóteses, a recorrer a comportamentos "auto-sensuais". É por isso que convém não retirar dele seu objeto autístico, que também é seu duplo.

Se Sellin (1994, p.190) não chega a falar, é porque ela se encontra aquém de todo espelho:

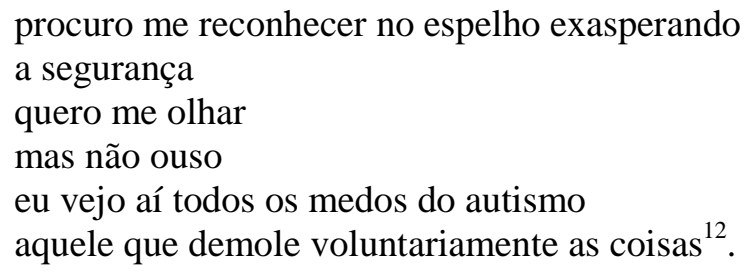

Ele espera poder, um dia, enxergar-se aí, mas testemunha uma posição subjetiva na qual está identificado ao objeto $a$, ele se vê como um detrito: "o idiota, o desorientado, o biruta, o neandertal", apenas esse objeto de horror poderia aparecer-lhe no espelho - é por isso que ele se vira. Em razão da ausência da imagem do duplo, ele não está em condições de dar um alicerce para sua enunciação; ora, o autista precisa de uma identificação imaginária transitivista para falar. $\mathrm{O}$ duplo que o protege do gozo do Outro está, para Sellin, encarnado em objetos concretos. Daí a necessidade de que seu braço esteja realmente conectado a um «facilitador» para que possa encontrar energia para escrever. Sabe-se que se trata de uma constante notável da "comunicação facilitada" com os autistas.

Um dos duplos de Williams, Carol, entrava no seu quarto pelo espelho. Assemelhava-se a ela traço por traço. Uma ínfima diferença as distinguia: "apenas o brilho [éclat] de seu olhar traía sua identidade". O olhar de Carol não abre para um abismo, o da subjetividade inapreensível da moça encontrada no parque, mas sim para um objeto suplementar, discernido em um "brilho".

Era Carol pura e simplesmente que eu via lá, afirma Williams. Comecei a falar com ela e ela me imitou. Isso me enraivecia, e eu lhe explicava que ela não precisava se divertir com isso, já que estávamos sozinhas. Passando adiante, ela começou a fazer tudo o que eu fazia. Eu perguntava o porquê, ela me devolvia a pergunta. Acabei por concluir que a resposta deveria ser um segredo [...] quando eu não encarava o espelho, ela desaparecia, e eu me sentia abandonada. Quando eu me voltava direto pro espelho, ela retornava, e eu tentava olhar atrás para ver se ela havia saído pela porta que percebia no plano-defundo. Por fim, aquela não era a porta que dava para o quarto do meu irmão, mas sim da sua casa. Quanto ao cômodo que via no espelho, ele era o lugar que servia de intermediário entre o seu mundo e o meu.

Entendi, então, o segredo. Bastava que eu penetrasse nesse cômodo de transição para poder ficar com ela e chegar ao mundo dela. Restava um último enigma: como entrar no espelho?

Eu tinha me dito que devia avançar direto para o espelho, se, porventura, quisesse entrar nesse cômodo. Foi o que fiquei tentando fazer os quatro anos seguintes ${ }^{13}$. Ia direto para dentro, e a cada vez me perguntava por que é que eu nunca chegava a passar através dele. (WILLIAMS, 1992, p.30-40) 
Williams faz suas tentativas insistentes num esforço de sair de sua solidão, procurando comunicar-se. Ela sublinha que a criação desse eu [moi] diferente encarnado em Carol "era mais que um jogo, mais que uma comédia. Era minha vida", escreve ela, "na qual era preciso que eu eliminasse o que se aparentasse a emoções pessoais e, ao mesmo tempo, que fizesse Donna desaparecer" (WILLIAMS, 1992, p. 42).

Ainda que ela sinta Carol e Willie como uma "mutilação" dela mesma - a saber, da autêntica Donna, mascarada atrás deles - ainda que ela tente proceder ao longo de sua adolescência a uma morte simbólica de Willie, seus duplos vão persistir tardiamente. Numa situação difícil, em Londres, depois da publicação de seu primeiro livro, para lhe permitir encarar o perigo, Willie ainda pode aparecer sem que ela se dê conta.

Contudo, muito progressivamente, seus duplos vão se desvanecendo. É preciso esperar seus 22 anos, segundo ela, para que vá procurar Donna no armário [placard] a que a havia relegado - e para que tome a decisão de fechar novamente o armário.

No segundo espelho, Carol não está mais presente: ela se integrou ao reflexo de Donna. A representação desta não é mais animal - ela não é mais um gatinho abandonado -; a integração dos duplos, mais brilhantes do que ela própria, produz um ganho narcísico. O aparecimento do Cão Viajante e do Urso Orsi é contemporâneo a esse segundo espelho: eles parecem participar de uma degradação de Willie e de Carol em objetos familiares reconfortantes, porém desprovidos de vida.

A passagem do primeiro ao segundo espelho não é um fenômeno próprio da especificidade do percurso de Williams. Um clínico como Lemay constata que a criança autista transpõe, primeiramente, situações concretas

mais facilmente com a ajuda de uma personagem do que por intermédio de seu corpo [...] por meio de uma contaminação imitativa imediata, é freqüente vê-lo esconder uma boneca em sua cama e, então, ele próprio entender como se a boneca e ele fizessem uma só unidade.

Ele constata que é preciso "esperar bastante tempo" para que o segundo espelho advenha, quando se põe a "imitar espontaneamente uma situação", colocando-se como ator (LEMAY, 2004, p.119).

Contudo, o reflexo de Donna não é uma imagem: trata-se sempre de um ser escópico vivo. Ela tem vinte e sete anos quando pede que uma de suas amigas olhe para o espelho junto com ela. Quando esta destaca seu olhar do espelho, Williams cai na risada.

— O que é tão engraçado? - pergunta-lhe sua amiga Kerry.

- Você olhou para outro lugar aí dentro - responde ela.

- E daí?

- O você ali não é o mesmo que o eu ali.

- É claro que não. Uma é a minha aparência e a outra é a sua.

- Nossas aparências não têm nenhuma relação, diz Williams, designando o reflexo de Kerry. - Mas ela desviou o olhar!

- Seu reflexo desviou também.

[...]

Eu ri disfarçadamente de seu erro, comenta Williams. Eu jamais a ${ }^{14}$ vi desviar os olhos. Quando eu a olhava novamente, ela me fixava como sempre. Eu acreditava no que me diziam meus olhos, e eles me indicavam que meu reflexo não desviava seu olhar. Eu 
podia recitar o fenômeno da reflexão sem, todavia, destruir a lógica da minha percepção; os dois não apareciam, pois, nunca juntos.

[...]

—- Nunca a vi desviando os olhos - disse eu.

— Se você está se virando, como pode ver? Onde estão seus olhos quando você vira a cabeça?

— Eles olham para outro lugar.

- O que é que você usaria pra ver se o seu reflexo desviasse a cabeça?

- Meus olhos, é claro.

Estudamos a questão em todos os sentidos, continua Williams,

segundo matemáticas mentais que eu não apreendia totalmente. A cada passo adiante eu perdia a ligação com o precedente. Compreendia o sentido de cada frase, mas não se tratava simplesmente de uma simples adição, e eu não estava compreendendo. Finalmente, depois de muitos gestos, trocas de papéis e observações disso que ocorria com ela no espelho, admito que Kerry tinha razão. (WILLIAMS, 1994/1996, p. 183-5)

Ela compreende pelo intelecto, mas o gozo que comanda sua percepção permanece não-integrado: segundo ela, se Donna e sua amiga colocam a mão no vidro, elas são quatro - elas duas mais "Kerry no espelho" e "Donna no espelho". Elas se seguram, então, todas as quatro, pelas mãos e "formam um grupo".

Contudo, esse espelho em que Donna e Kerry aparecem no mundo invertido, Williams certamente ainda não está pronta para aceitar: ela deve estar sozinha. No início da cena, ela pede que Kerry toque no seu reflexo ao mesmo tempo em que nela própria, e muito rapidamente isso fica insuportável: "Vai embora, ordenava eu subitamente ao reflexo de Kerry. Sai daí. Não a queria mais no espelho comigo."

Entretanto, ela lamenta que Kerry aceite o seu pedido; ela já tem a intuição de que o terceiro espelho, no qual aceita a presença de um objeto, estaria em progresso com relação àquele pelo qual ela ainda está capturada. No segundo ela não habita o seu reflexo - ele possui uma vida independente, que traduz seu modo de recusa do gozo [rejet de la jouissance] - ela não possui seu corpo, ele é um objeto "horrível" que a captura, com o qual ela não tem nem "laço emocional", nem sentimento de pertença. Ela não tem intimidade consigo mesma. Concebe a existência de seu corpo, mas não aceita aquilo que dele experimenta.

A consistência do mundo do espelho, que comanda sua percepção, às vezes se impõe a ela. Em momentos de angústia sua visão se desestrutura, ela não consegue se orientar a partir de seu reflexo, como se visse o mundo pelos olhos dele, como se ele fosse a fonte do gozo escópico. Pouco depois de ter obtido seu diploma universitário, conheceu um período particularmente difícil, durante o qual sua concentração intelectual não chega a impor sua lógica ao mundo à sua volta. Outra lógica se impõe, então: a do espelho invertido. "O universo inteiro", relata ela,

parecia revirado: a cabeça embaixo, o interior do lado de fora, o atrás na frente. Tudo parecia ser sua própria imagem invertida, como se, no momento em que estava entrando num cômodo, eu tivesse entrado num espelho.

Não botava mais a mão no carro, horrorizada. Conhecia o nome das ruas e jamais tinha tido problema algum em encontrar o caminho. Mas eis que era preciso guiar seguindo o nome das ruas que eu conhecia, como numa cidade desconhecida.

$\mathrm{Ou}$, antes mesmo, tudo acontecia como se eu rodasse no espelho: encontrava-me, rua após rua, no oposto de onde eu queria ir. Acabava, então, do outro lado da cidade! Ao 
invés de retornar para casa, tinha guiado no outro sentido. As coisas e os lugares estavam transformados cada qual no seu contrário. Isso durou dois dias. Achei que estava ficando louca. (WILLIAMS, 1996, p.232)

O que ela vê no espelho não é uma fantasmagoria: é a lógica de sua posição subjetiva. Quando a mestria intelectual não basta para dirigir sua percepção, ela pode perceber o mundo a partir de seu reflexo, porque o gozo é fundamentalmente descarregado [rejeté] neste último. Esse mecanismo de defesa para governar as emoções, para tomar distância do vivo, está no princípio do autismo. É pelo fato de seu ser de gozo estar na imagem que ela apreende que, numa foto, ela está presa - o que lhe dá a sensação de que "se apossam" dela. "As pessoas conservavam você no papel e você olhava nos olhos para saber se estava lá. Então você estava exposto e congelado no tempo. Você não pode fugir." (WILLIAMS, 1996, p.207)

Não somente acontece de Williams "rodar no espelho", mas sua percepção daqueles que a rodeiam é estruturada pelo ser escópico que capta seu gozo: ela só pode apreendê-los como imagens. É por isso que, numa disciplina de educação esportiva, durante seus estudos rumo ao diploma de educadora infantil, ela não reconhece mais os outros estudantes quando os vê despidos.

"Eles eram irreconhecíveis", relata ela. "A imagem de meus colegas de classe se fundia numa massa de corpos negros, brancos e sardentos [tachétés], numa imagem de desconhecido" (WILLIAMS, 1996, p.115). A ausência de pertença de seu próprio corpo não lhe permite apreendê-lo do interior. "O que eu via", explica ela, "era tudo o que havia. Eu via uma mancha. Não via braços. Não associava sistematicamente a presença de um braço na mancha com o contato do braço através do da mancha" (WILLIAMS, 1996, p.189). De novo, constata-se que seu mundo singular de gozo escópico se impõe ao seu intelecto, ela mesma esclarece através de que meio: rompendo as cadeias associativas. A mancha é uma primeira parte; o braço, uma segunda - o laço [lien] não ocorre entre os dois. "Tendo chegado à segunda parte, havia perdido a primeira, e cada uma delas era armazenada separadamente". A apreensão do corpo próprio no segundo espelho é necessariamente fragmentada, ainda que o reflexo permita que se juntem seus elementos.

Uma posição subjetiva assim não impede Williams de obter um sucesso brilhante no exame, permitindo que se torne educadora infantil; entretanto, ela não tem a "impressão de ser um sucesso real. Eu tinha ensinado sem a ajuda de Willie e Carol", comenta ela, "mas sempre fazia apelo a vozes, a expressões faciais e a gestos memorizados». Certamente não são seus duplos que falam - ela constata um progresso, sente-se menos mutilada - mas seu funcionamento conserva algo de mecânico: ela age sem sentir; seu intelecto continua cortado de seu gozo; ela ainda toma a palavra a partir de seu reflexo não integrado.

Ela não se satisfaz com isso. Sabe que os outros ainda habitam seu corpo, mas como conseguir? O tratamento com o Dr. Marek talvez a tenha ajudado a abandonar seus duplos, deixando Donna mais amável, já que melhor adaptada; mas não a conduziu ao terceiro espelho, aquele que permite chegar à pertença de seu corpo. Este não teria como se adquirir apenas através do trato do Outro de síntese: é preciso outra coisa. Um acontecimento que não se programa e que chega a modificar o modo de gozo do sujeito.

O terceiro espelho aparece quando ela se aproxima dos seus trinta anos. Ela está morando, então, na Inglaterra. $\mathrm{O}$ sucesso mundial de seu primeiro livro lhe deu a possibilidade de deixar sua Austrália natal. Estava fugindo menos dos homens que lhe interessavam, experimentando sentimentos amorosos por alguns. Ela acaba de tomar a 
decisão de empreender a escrita de um novo livro. No término de sua segunda obra, intitulada Alguém, algum lugar - e não mais Ninguém, parte alguma - ela não está mais sozinha no espelho: outro objeto narcísico se introduz aí.

Eu gostava de ter tanto tempo pra mim, relata ela, e de me possuir integralmente, sem personagens. Eu me atirava no banheiro:

- Bom dia - eu me dizia no espelho.

Aí eu conversava durante certo tempo. Às vezes me perdia longamente nos meus olhos. Pintei-me um espelho pendurado na parede da sala, com ervas altas no primeiro plano e um quadro de roseiras-bravas de todas as cores. Eu me esticava pra frente de uma maneira que parecesse alongada na erva alta do mundo invertido; o sol do quadro brincava loucamente sobre a erva, e dava a ela todas as nuances de verde, de dourado e de castanho.

Às vezes levava minha refeição para comer comigo no espelho. Estávamos as duas sentadas na erva bela, selvagem, alta e movente. Juntas, rodeadas de rosas, havia somente eu e eu no espelho. Sem lugar. Sem mundo. Sem solidão. Os outros não eram mais tão inoportunos desde que eu estava passando tanto tempo comigo. (WILLIAMS, 1996, p.275)

Ela se ama nesse espelho: aí eu estou, afirma ela, "em casa comigo [chez moi avec moi]". O reflexo continua real, trata-se sempre de uma presença viva, de um ser escópico. Uma versão posterior desse mesmo espelho confirma isso, quando Williams, na presença de seu amigo Ian, afirma novamente "sentir" a presença de seu reflexo. Ela lhe explica "sua obsessão pelo reflexo", pela intimidade que encontra em sua contemplação. Certamente, não está mais sozinha no terceiro espelho: uma paisagem florida a cerca. Esta foi desenhada sobre o vidro. A imagem de um objeto narcísico separado do reflexo se introduz na apreensão de sua posição subjetiva.

Quais são os candidatos a assumir a posição de objeto florido em sua realidade? São dois. Em primeiro lugar, Ian, um amigo autista de quem ela está gostando. "Um laço precioso" se teceu com ele; ela experimenta "um sentimento de pertença" na sua presença, mas quando ela lhe faz notar que o vê no espelho com ela, ele recusa entrar: "Não estou no espelho", diz Ian, apreensivo. "Eu estou aqui. Sou real. Isso, isso não é real. Você não pode tocar um reflexo." (WILLIAMS, 1996, p.307). Um parceiro humano poderia, sem dúvida, instalar-se no lugar de um objeto de completude imaginária, mas Williams ainda não o encontrou no final de Alguém, algum lugar. Em contrapartida, o segundo objeto já está integrado em seu mundo: é aquele pelo qual ela foi coberta de flores; a saber, sua primeira obra, best-seller mundial, extensão de seu mundo interior rumo à realidade social.

A introdução do terceiro espelho em Alguém, algum lugar faz imediatamente seqüência à sua decisão de empreender a escrita do segundo livro. Além disso, os traçados feitos sobre o espelho são signos icônicos, em conexão rígida com seu referente - sabe-se que a escrita saiu de sua estilização ${ }^{15}$, o que incita colocá-los em correlação com o livro.

As decisões de escrever e, sobretudo, de publicar Ninguém, parte alguma modificaram a posição subjetiva de Williams: revelando a todos o seu mundo íntimo, ela efetivou um ato decisivo que a modificou. Percebe nitidamente ter cedido ao gozo inerente ao seu mundo autístico seguro, quando sublinha que a redação de seu livro, desnudando seu "mundo", fragilizou e desestabilizou "sua empreitada" (WILLIAMS, 1996, p.97). Da mesma forma, sua publicação "embrulha seu estômago", em razão da "ausência de controle" [maîtrise] devida ao seu "comprometimento" (WILLIAMS, 
1996, p. 237) Ela não esconde a angústia mobilizada pela publicação: “o manuscrito ia ser desvendado ao mundo, e a idéia de que fosse lido ainda me deixava paranóica. Num ato de desespero eu o havia submetido a um olhar. Divulgado, meu antigo mundo seria violado para sempre por esse desnudamento" (WILLIAMS, 1996, p.9). Esse manuscrito, acrescenta ela, "tinha sido meu melhor amigo e meu pior inimigo. Ele havia tanto me salvado, quanto destruído". Separando-se dele, ela cede aos outros um objeto precioso, o que a "destrói", introduzindo a dimensão da falta [manque] em sua subjetividade. Uma falta que permanece, apesar de governada [maîtrisé]: o objeto não cessa de pertencer a ela, é seu "melhor amigo", e ela pode, inclusive, produzir um segundo.

Ela ratificou, por outro ato decisivo, a decisão de deixar seu mundo autístico: depois da publicação de sua primeira obra, ela escolhe abandonar sua Austrália natal para ir morar na Inglaterra. Para nomear seu novo país de residência, utiliza bastante freqüentemente a expressão: "Reino-Unido". Sem dúvida é preciso entender que ela veio morar no que para ela é um "reino" não mais caótico, e sim "unido".

$\mathrm{Da}$ mesma forma que Willie fora construído sobre uma captura do objeto escópico $^{16}$, as flores no espelho testemunham a inserção do olhar no livro. O descolamento que se opera graças à sua publicação intervém no tratamento do gozo escópico, permitindo que Williams se perceba pela primeira vez sem estar colada no seu reflexo, a partir desse olhar distanciado. Os efeitos na sua apreensão dela mesma são espetaculares.

Até então, relata, quando ela entrava num cômodo, a participação de sua imagem se pautava no reflexo percebido na imagem dos próximos.

Eu sempre havia tido a impressão de ter a estatura das pessoas por perto. Eu tenho um metro e cinqüenta e seis: elas eram, pois, geralmente maiores que eu. Quando me via com pessoas de baixa estatura, supunha ser pequena; com pessoas grandes, me achava grande. Na falta de um sentido de meu corpo interno, elas me serviam de espelho, de mapa exterior.

O terceiro espelho testemunha uma modificação desse funcionamento: ela fica em condições de se perceber num outro lugar que não no seu reflexo real. Nas últimas páginas de sua segunda obra relata ter provado, na companhia de Ian, sensações que lhe parecem "medonhas e incompreensíveis" de início.

— Estou sentindo minha perna - gritava eu em pânico. Estou sentindo minha mão e minha perna.

Estava com medo e tremendo. [...]

Colocava minha mão sobre meu braço e murmurava com receio.

- Tenho um braço.

Não o sentia sob a minha mão do exterior, como antes, mas do interior. Meu braço, o havia percebido do interior. Braço não era mais que uma simples textura; ele estava tomando sentido do interior.

Era estranho e, portanto, pavoroso. Eu era uma estrangeira num veículo que me transportava, mas que vinha justamente me assinalar que estava lá, que era real, que pertencia a mim e que fazia parte de mim. [...]

Eu nunca havia me sentido tão totalmente viva [...] Essa possessão de mim era a segurança mais tangível que eu havia por ventura conhecido. (WILLIAMS, 1996, p.313-5) 
O "estranho" foi introduzido no espelho: produzindo, pela decisão da publicação, uma perda do objeto na qual o gozo encontra sua dinâmica - a economia do gozo encontrou-se modificada; uma parte dela se deslocou do reflexo para o livro. O ser "estranho" não é mais totalmente rejeitado no reflexo, este perde sua "vividez", seu poder de captação se atenua, a integração de sua imagem lhe é possibilitada. Williams fica em condições de se apropriar de um eu [moi]: parte dela mesma com a qual ela se experiencia à distância, mas num laço íntimo. A integração do duplo lhe permite começar a sentir certas sensações, porque seu gozo não é totalmente rejeitado: ele se reparte entre o sujeito e seu objeto. Ela não está mais sozinha no espelho, mas vê aí um eu [moi] narcísico completo por meio de um objeto que a colmata: ele se espelha no livro.

O terceiro espelho de Williams, por sua inserção de flores na imagem do corpo, evoca fortemente a imagem real que se produz no esquema óptico, quando Lacan - para produzir uma articulação estrutural do estádio do espelho com o campo simbólico - se apropria da ilusão do buquê invertido de Bouasse. Contudo, ele a transforma e acrescenta um segundo espelho, o do Outro, no qual se produz uma imagem virtual. Sabe-se que as imagens que, nesse esquema, formam-se nos espelhos conjugam dois elementos separados: a imagem do corpo (figurada pelo vaso escondido), e os objetos do desejo (encarnados pelas flores) (LACAN, 1998). Os três espelhos de Williams permanecem espelhos reais, demarcados à esquerda do esquema óptico; isso que se produz no campo do Outro, no qual aparece uma imagem virtual, não advém. O espelho real permite unificar a imagem do corpo, mas não dá acesso à regulação sobre o ideal do eu.

Williams não chega ao estádio do espelho. Em seu funcionamento subjetivo, a perda se ilustra [met en image] aquém do espelho, e não além; certamente ela descola o sujeito de seu duplo, mas não é ela que produz uma queda do objeto $a$. Sabe-se que, na cena da criança no espelho, ela não é totalmente capturada por seu reflexo: uma presença Outra, que a assiste, faz com que ela se vire e descubra, no espaço em que ela está, um olhar posto sobre sua imagem, mascarado no espelho por esta última. Ora, quando Williams se observa na companhia de Ian, ela não se vira em direção a ele - para buscar seu olhar - ela procura encontrá-lo no espelho. O objeto olhar, que orienta o gozo escópico, não está, para ela, perdido atrás do reflexo: ele ainda o habita. Às vezes, Williams o discerne - quando, num momento de angústia, ocorre a ela achar insuportável que seu reflexo a olhe. "Ela está olhando", diz para Ian, "não posso suportar isso. Ela está olhando" (WILLIAMS, 1996, p.307).

Williams tem a sensação de que será preciso abandonar a dependência do seu reflexo para obter uma verdadeira integração deste. Ele permanece real, vivo, mas completo, por meio de um objeto narcísico; isto é, de uma só vez amável e parecido com ela, o que reflete muito precisamente sua vida sentimental: quando ela sente algo, trata-se sempre de homens como ela - é seu funcionamento que os torna, não desejáveis, mas atraentes. Não são satisfações sensuais que ela procura, muito pelo contrário, mas um sentimento de "pertença", de fusão com o outro, tal qual as flores do quadro.

Que a perda de gozo não seja simbolizada pela função fálica, que a operação de separação não seja assumida: é isso que sua busca por uma "relação assexual platônica" atesta. Ela não está numa posição subjetiva que lhe permita colocar sua própria falta [manque] a serviço da falta do Outro. A integração de seu reflexo lhe dá acesso a uma melhor apreensão de seu corpo, mas seu gozo continua essencialmente cindido de seu intelecto, rejeitado num objeto que o capta e o regula - a saber, seus livros. 
Todavia, depois da publicação de Alguém, algum lugar, Donna Williams se casou. Provavelmente com um outro autista. A relação de objeto permanece, para esses sujeitos, marcada pelo empreendimento do duplo.

Os casamentos mais exitosos - relata Grandin - que muitos autistas de alto funcionamento encontraram são aqueles que unem dois autistas, ou mesmo um autista e uma pessoa deficiente ou fora da norma. As duas pessoas se dão bem porque partilham interesses comuns, não porque são fisicamente atraídas uma pela outra. Elas são atraídas uma pela outra porque têm um funcionamento intelectual parecido. (GRANDIN, 1997, p.155)

$\mathrm{O}$ amor, nos autistas, parte do intelecto. Ele deve permanecer governado [maîtrisé]. Se intenso demais, faria correr o risco do caos emocional.

Williams pode dar o passo seguinte na sua relação com o espelho? $\mathrm{O}$ autista pode chegar ao especular, isto é, ao estádio do espelho? A tese dos Lefort faz dessa impossibilidade uma característica da estrutura autística. Entretanto, Williams constata que não são todos os autistas que, com relação ao espelho, passam por dificuldades comparáveis às suas. Seu amigo Ian, por exemplo, mostra-se ter um sentido do corpo interno bastante mais intacto que o seu.

\section{NOS LIMITES DO ESPECTRO DO AUTISMO}

O espelho de Temple Grandin, tal como aparece na capa de Thinking in pictures, na qual está junto de seu duplo, mostra-se um pouquinho diferente. A foto representa Grandin sentada na palha, cara a cara com uma vaca imponente, com uma mão no focinho e a outra dando de comer pra ela. As personagens ocupam toda a foto, mascarando o fundo. Grandin supõe que os animais pensam, como ela, por imagens; de modo que considera poder facilmente colocar-se na pele de uma vaca, a fim de ver o mundo através dos olhos dela. Essa capacidade é essencial no seu métier, já que é uma especialista em bretes, que servem para marcar, vacinar ou castrar os animais.

Havia pensado, em princípio, em intitular sua segunda obra como $O$ ponto de vista de uma vaca; ela esclarece: "quando me imagino no lugar de uma vaca, preciso verdadeiramente ser uma vaca, e não uma pessoa disfarçada de vaca [...] Coloco-me no interior de seu corpo e imagino o que ela sente" (GRANDIN, 1997, p.14 e 166). A capacidade de conectar-se imaginariamente ao sentimento do duplo que a completa indica nitidamente uma relação de integração com ele. Essa integração traduz-se clinicamente numa certa apropriação do sentimento e num ganho de uma animação libidinal do sujeito independente de seu objeto. É o que constata Grandin quando lhe fazem notar que a entonação de sua voz melhorou, tornando-se menos apagada, mais vívida. Ela pensa que o fenômeno está ligado a um aumento de sua percepção social e ao fato de que ela não precisava mais dessa defesa contra o mundo exterior (cf. GRANDIN, 1999, p.90).

Deve-se, sobretudo, notar que nesse espelho ela saiu de seu isolamento: dois objetos estão aí presentes - sua imagem e a de uma vaca -, o que só se produz por ocasião do último espelho do autista. Ele deixa de incluir, não mais que os precedentes, a falta simbólica: mostra-se ser um quadro do sujeito completo por um objeto. Essa posição subjetiva permite que a divisão no imaginário permaneça sob controle [maîtrisée]. 
Pode-se formar, em Grandin, outras imagens além daquela que a mostra com uma vaca. Na seguinte forma, por exemplo: "só depois", explica ela, "de ter tirado uma foto (que mandei ampliar e emoldurar) de mim mesma no brete, pude encarar os meus medos. Estava chegando finalmente ao ponto em que conseguia pensar no meu brete com prazer e afeição» (GRANDIN, 1999, p. 118). Nota-se que, sendo seu duplo integral, ela não tem a sensação de que seu ser é captado pela fotografia, de encontro com o que Williams sente no seu segundo espelho. Ela pode, então, pendurá-la para contemplar sua imagem, confiante porque completa por meio de um objeto, e dinâmica porque independente desse objeto - o que clinicamente atesta a incorporação de uma certa autonomia subjetiva.

$\mathrm{Na}$ imagem precedente, o objeto que a completa não está no espelho: trata-se da máquina de compressão, derivada do brete - máquina de captar e regular seu gozo, cuja construção ela considera como estando constituída pelo elemento essencial de sua autoterapia ${ }^{17}$. O "conceito" que preside sua construção, esclarece ela, é o de um "meio de contenção". Graças a esse aí, ela aprendeu a dominar sua agressividade, a aceitar que testemunhem afeto por ela.

Ela guarda permanentemente em seu quarto essa máquina inspirada nos bretes; utiliza-a para aquietar seu sistema nervoso e suas emoções. Coloca-se no lugar do animal, completando-se com uma máquina "que se molda ao corpo do usuário". Ela se regenera ao se fundir com o objeto da falta imaginária, e ele chega a temperar seu nervosismo excessivo quase permanente. Ela encontra nisso, então, um estado de relaxamento - a propósito do qual confia a Sacks supor que "as pessoas cheguem a isso por intermédio de relações com os outros" (SACKS, 1997, p.271). Sua identificação transitivista com um objeto autístico complexo lhe permite, com efeito, juntar-se ao campo do Outro, mas falha em posicionar o objeto na falta do Outro; ela ilustra a nãopermanência dessa ligação, e o trabalho intelectual que ele necessita por parte do sujeito.

Em Williams, o objeto de completude está traçado no espelho; em Grandin está fora. Apesar disso - esteja a imagem de Grandin ligada ao animal ou ao brete -, trata-se sempre de um espelho estruturalmente idêntico ao terceiro espelho de Williams. Grandin encontra-se numa posição subjetiva aparentada à de Williams. Uma nuance, contudo: seus objetos no espelho são mais rudes do que são as flores da australiana. A imagem de Williams é falicizada por seus duplos humanos e "brilhantes" - os homens que vêm rumo a essa bela mulher -, ao passo que a de Grandin é apagada - fizeram-na notar que lhe falta "sex-appeal" (GRANDIN, 1999, p.90): sua identificação com a vaca não a deixava mais bonita; houve. até mesmo, um tempo em que se sentia mal. Ela renunciou ao seu casamento. Contudo, chega a uma notável autoterapia que a tirou do retraimento.

Ela insiste muito, em sua primeira obra - Uma menina estranha -, no fato que relata "a transposição" de suas "portas simbólicas rumo ao triunfo"" (GRANDIN, 1999 , p.148 $)^{19}$. Essa transposição encontra sua fonte numa fala de um pastor, tomada ao pé da letra, tirada do Evangelho de João, "Eu sou a porta: por mim, se algum homem entrar, será salvo." ${ }^{20}$ Grandin procura, então, na sua escola, a porta que, para ela, abre rumo aos céus. Descobre-a numa pequena porta de madeira que dá para o telhado. Ela a atravessou, mas foi surpreendida, e a interditaram. O que é que você está procurando aí em cima? "Eu", responde ela. Minha vida. Deus". Sublinha a importância que o atravessamento dessa porta ganha para ela na adolescência; e ela, apesar da interdição, reitera: 
Descumprir as regras era algo que eu não tinha superado. No Observatório, pensava sobre a autoridade e as regras. Quando passei para o telhado pela portinha de madeira, estava ultrapassando a autoridade da escola. De início, achei que, depois de passar pela porta, eu me encontrava além do alcance de qualquer autoridade humana - regras, leis - e que além da porta estava eu, Deus e a liberdade de escolha. Depois percebi que além da porta ficava a autoridade, também, mas a autoridade dentro de cada um. (GRANDIN, 1999, p. 86)

Em seguida ela empurra outras portas - ato que concebe cada vez como sendo "uma forma de tornar efetiva a tomada de uma decisão". Ela simboliza escolhas decisivas através dessas transposições reais, tais como a de deixar o liceu e de se preparar para a universidade, que a impulsionam rumo a uma saída de seu mundo autístico. Por que Grandin retorna com insistência ao fato de que a transposição real de suas portas simbólicas escande momentos essenciais de sua autoterapia? Porque ela ilustra uma corrida de risco da sua parte, transpõe o interdito de dominação que rege o mundo autístico - resumindo, ela faz um ato. Um ato autêntico que é a sua garantia, que rompe com o intelecto, que não pode estar inteiramente fundado em razões. A convocação de seu corpo e de sua motricidade, no ato de transposição, indica que ela deve colocar seu próprio gozo em jogo.

É impressionante que Lacan tenha recorrido precisamente à mesma imagem que Grandin para ilustrar o que é um ato: "Se posso caminhar aqui de um lado para o outro enquanto falo com vocês", explica ele em seu seminário de 15 de novembro de 1967, "isso não constitui um ato; mas, se um dia vier ao caso transpor um determinado limiar em que me ponho fora-da-lei, esse dia minha motricidade terá valor de ato" (LACAN, 1967-68). Atravessando a porta do interdito, Grandin cede ao seu domínio, põe em jogo uma falta [manque], encontra-se modificada por ela. Uma modificação da economia do gozo é consequiência disso.

Ela sublinha a importância para o sujeito autista de uma tomada de consciência de suas dificuldades; isto é, a apreensão de algo lhe falta com relação aos outros. Ela aponta que Kanner já havia feito essa constatação em determinada ocasião, seguido de noventa e seis crianças autistas. Entre essas, as onze que tinham atingido uma boa autonomia na idade adulta distinguiam-se por uma "mudança de comportamento nascida da motivação pessoal na adolescência [...] Contrariamente à maioria das crianças autistas", escrevia Kanner, "elas tomam consciência com inquietude de suas bizarrices e começam a fazer esforços conscientes para modificá-las." (KANNER; RODRIGUEZ; ASHENDEN, 1972, p.9 e 33). Indicação preciosa para o tratamento, confirmada pela maioria dos autistas de alto funcionamento, ela incita a dar um lugar à falta do sujeito e a não se precipitar, colmatando-a.

Tanto Grandin quanto Williams chegaram a tomar decisões dolorosas, sem a garantia de estarem fazendo bem, colocando em jogo a assunção de uma perda, obtendo êxito, assim, em livrar-se progressivamente de suas defesas autísticas mais radicais. A partir de seus testemunhos, parecem poder ser evidenciadas quatro grandes posições subjetivas que escandem a saída do fechamento autístico - uma vez que se apóia no exame dos espelhos.

Do primeiro, o sujeito se vira, acreditando perceber nele seu ser como dejeto [déchet] - ele se encontra, então, submetido ao gozo do Outro, sem a proteção de um 
duplo. No segundo espelho um objeto capta seu gozo - ele se situa numa dependência dolorosa com relação a este (máquina, amigo invisível, animal etc.), mas se anima em se sintonizar com ele. No terceiro, o objeto é mais bem aceito, porque ele representa o sujeito sem mediação (ser escópico do reflexo, produção, tal como o livro de Williams antes de sua publicação, sujeito disfarçado de marciano ou de Viking); ele constitui, ainda, o ponto de inserção do gozo. No último, o sujeito não está mais sozinho: ele se encontra dividido por um objeto de cujo domínio, contudo, ele se protege - o gozo com o qual se anima, se reparte entre seu ser e seu objeto; daí a sensação de integração do duplo e a aptidão para investir um objeto dotado de uma independência controlada (máquina de compressão, livro depois da publicação, parceiro humano).

Para transpor as etapas que podem conduzi-lo a um assujeitamento imaginário ao Outro, por intermédio de uma identificação transitivista, o sujeito autista dispõe de dois objetos nos quais se apóia. Eles não são totalmente independentes: o duplo e o objeto autístico interferem no espelho. O objeto autístico participa do duplo, ao passo que o duplo pode tornar-se um objeto autístico. Williams, com Carol e Willie, chega a levar ao mais alto grau a construção do duplo, dotando-o de capacidades extraordinárias de adaptação ao outro mundo. Ela sublinha, contudo, o quanto essa via é mutiladora para o sujeito.

Grandin tentou, também ela, construir amigos invisíveis (Bisban, Alfred Costello), mas soube tirar melhor proveito de um amparo no objeto autístico. Ela evidencia a função deste de maneira bem pura, pois chega a descolá-lo do espelho. Sua máquina de compressão continua, certamente, em conexão com seu duplo - originou-se de uma adaptação do brete; ela mesma se instala na máquina na mesma posição que o gado -; contudo, trata-se de um objeto autístico que não é um duplo do sujeito: serve para tratar o duplo, mas ele próprio não o é. A última máquina de Joey, um retificador elétrico, parece ser da mesma ordem: regula a própria energia de que Joey precisava em sua infância - o sujeito comparece sempre por ele sobrecarregado, mas nada indica que seja também um duplo.

Quando o objeto autístico é elevado ao mais alto grau, descola-se do duplo para articula-se de maneira estreita ao Outro de síntese - ele próprio desenvolvendo os pontos de competência, de tal modo que tanto Grandin quanto Joey encontram no seu objeto autístico o fundamento de sua inserção profissional e social. Uma se torna especialista mundial em confinamento de gado, o outro encontra um métier na eletrônica.

Frequientemente tem-se constatado que as atividades profissionais dos autistas têm origem em seus objetos autísticos complexos, que se caracterizam por estar articulados aos pontos de competência. Para a família, os pontos de competência são freqüentemente considerados como obsessões - uma vez que o sujeito, durante certo período, só se interessa por isso e só fala disso. São portadores de uma dinâmica que convém encorajar. Grandin sublinha que sua tendência à obsessão lhe forneceu uma importante motivação para desenvolver suas pesquisas universitárias a respeito do confinamento do gado. "A tendência à obsessão", escreve ela, "é um traço humano normal, mas os autistas a possuem em muito mais alto grau." (GRANDIN, 1999, p.132). Foi o que a levou, depois de sua tese, a publicar mais de uma centena de artigos sobre o tratamento do gado na imprensa profissional dessa indústria. "Um homem que tinha uma fixação infantil em números", afirma Grandin, "hoje trabalha preparando relatórios de eficiência fiscal." (GRANDIN, p.148)

O desenvolvimento do ponto de competência, que implica uma grande propriedade intelectual sobre um domínio circunscrito do saber gera, por vezes, 
estabilizações originais que passam pela criação de um mundo totalmente sob o controle do sujeito. Gilles Tréhin ${ }^{21}$ consagrou um trabalho considerável à edificação de uma cidade imaginária que nomeou Urville. Ele compõe em detalhes sua história, geografia, economia, organização política e arquitetura. Esclarece que ela dispõe de uma tribuna de segunda instância, de um tribunal criminal, um tribunal de instância superior, uma universidade, um arcebispado, uma Bolsa, importantes museus, mais de trezentos teatros, trinta jornais nacionais, numerosas editoras etc. Ele publicou inúmeros desenhos e plantas que deram a ela uma consistência extraordinária (TRÉHIN, 2004) ${ }^{22}$.

Sacks encontrou uma família de autistas que havia desenvolvido uma construção parecida. O Sr. e a Sra. B., e seu filho mais velho, relata ele,

passaram anos construindo um mundo imaginário com paisagens e geografia próprias (infinitamente mapeadas e desenhadas), línguas próprias, moedas, leis e costumes - um mundo onde a fantasia e a rigidez têm o mesmo peso. Podiam, portanto, passar dias calculando a produção total de grãos ou as reservas de prata na Leutéria, ou desenhando uma nova bandeira, ou equacionando os complexos fatores para determinar o valor de um thog. (SACKS, 1997, p.282, rodapé)

Tais mundos são inserções de um mundo autístico no mundo exterior; contudo, eles incitam aqueles que os criam a adquirir conhecimentos aprofundados em diversos domínios e a utilizá-los - o que lhes permite articular os dois mundos e melhorar sua função social. Menos promissor para o sujeito autista de alto nível é o prolongamento de seu mundo autístico num mundo imaginário já constituído - o de Tolkien, de Lewis, do Star Wars, do Dungeons \& Dragons ou de um universo disponível na Internet. Certamente ele chega, em regra geral, a adquirir um conhecimento enciclopédico, mas que não pode ser utilizado facilmente para confortar o retraimento.

Mais do que tomar apoio no ponto de competência, certos autistas privilegiam as possibilidades do duplo. Essa via não é sem promessa, com a mesma condição de que o objeto chegue a uma articulação com o Outro de síntese. Nazeer e Craig conseguem isso tendo como profissão escrever textos para os duplos: um e outro redigem discursos de políticos de cujas convicções partilham, sem jamais - saibamos disso - pronunciá-los eles próprios. (NAZEER, 2006).

Certos autistas de alto funcionamento praticamente não são tomados como autistas por aqueles que convivem com eles. Assim, Craig, segundo Nazeer, possui uma vasta caderneta de endereços profissionais; é membro de um clube de golfe chique idealizado por famílias eminentes; é capaz de fazer piadas num fim de tarde; é, aliás, um belo rapaz, que tem aventuras amorosas com mulheres que não conhecem seus problemas. Ele foi, na infância, colocado numa classe especial para autistas, e na idade adulta, seu funcionamento permanece autístico. Para ele, assim como para Nazeer, esse último praticamente não transparece àqueles que não o conhecem intimamente. Certamente os outros poderiam notar alguns problemas de dicção, alguns comportamentos bizarros, uma tendência a fugir dos contatos sociais e uma certa dificuldade de, nesses dois homens, assumir uma posição viril ${ }^{23}$ : eles não sabem assoviar, nem brigar (NAZEER, 2006, p.135). Mas tudo isso permanece discreto e pode facilmente passar despercebido.

As autobiografias de autistas de alto funcionamento são freqüentemente recusadas pelos especialistas, que geralmente encontram críticas virulentas ao saber que elas pretensamente conteriam. Alguns doutos convocam, então, explicações circunstanciais para minimizar o alcance inovador desses testemunhos. Fazem-se, 
assim, hipóteses de que seus discursos sobre si mesmos seriam o decalque exato daquilo que se diz sobre eles, oriundo das crenças de seus familiares, de tal modo que não teríamos nada a aprender com eles.

De fato, se há um discurso sedutor para o autista - que procura apreender tudo pelo intelecto -, um discurso que captaria voluntariamente de seus familiares é, seguramente, o da ciência: o da exclusão metódica - que se encontra em seu princípio do sujeito e de seu gozo. Portanto, quando se constata que Williams parece ter estado procurando seus espelhos no pré-especular da imagem real do esquema óptico, ao passo que Grandin parece ter encontrado sua concepção das portas simbólicas num seminário de Lacan, é preciso convir que eles emitem um saber que vai bem além do que a ciência pode disso dizer. Eles testemunham um saber que os ultrapassa, é por isso que não se teria como duvidar do fato de que sua subjetividade esteja aí engajada.

A dificuldade em identificar as formas discretas do autismo constitui uma das principais razões pelas quais a extensão do espectro sindrômico conhece variações consideráveis em função dos métodos utilizados para circunscrevê-lo. A ocorrência da síndrome de Asperger seria de 7,1 para 1.000 crianças, conforme um estudo; e de 2,5 para 10.000, conforme outro! (EHLERS; GILLBERG, 1993; FOMBONNE; TIDMARSH, 2003)

A noção de espectro do autismo continua vaga. Ela supõe, contudo, uma grande variedade de manifestações de um mesmo funcionamento subjetivo; portanto, tem o mérito de sugerir a existência de uma estrutura subjacente a quadros clínicos bastante diferentes. Implica, além disso, uma tese às vezes desconhecida, a saber: a de que a grande maioria dos casos de evolução do autismo faz-se não rumo à psicose, mas rumo ao autismo, da síndrome de Kanner para a de Asperger - até mesmo rumo a formas ainda mais discretas, às vezes qualificadas como «personalidades dependentes». Certamente se faz menção a certas passagens do autismo à esquizofrenia, mas nada é mais difícil de diferenciar de um esquizofrênico do que um autista ao qual não foi dada a possibilidade de construir sua borda.

Uma abordagem puramente educativa do autismo - que repousa no saber do educador, sem dar lugar à subjetividade e às suas escolhas - melhora, certamente, em regra geral, o comportamento social, mas praticamente não permite conseguir a divisão imaginária pela qual o sujeito autista adquire uma autonomia. Ainda convém, a esse respeito, distinguir entre o método Lovaas ${ }^{24}$ - violência feita ao sujeito autista, que convém rejeitar absolutamente - e o método Teacch ${ }^{25}$, que repousa num autêntico conhecimento do funcionamento intelectual dos autistas. Tomemos conhecimento de dois testemunhos qualificados sobre os efeitos desses métodos: um de Williams, para o primeiro; o outro de Sacks, para o segundo.

Williams, nos anos de 1990, fez um estágio na Austrália, numa casa especializada em crianças com dificuldade. Ela observa aí dois educadores fervorosos no seu trabalho com uma autista. Fica chocada com o desconhecimento que apresentam a respeito do mundo interior da criança.

Fui ficando doente, escreve ela, de vê-los invadir o espaço pessoal dela com o corpo, o hálito, os odores, os risos, os movimentos e os barulhos. Quase loucos, eles agitavam chocalhos e objetos diante dela como dois feiticeiros demasiadamente fervorosos, esperando exorcizar o autismo. Segundo eles, aparentemente, era preciso uma overdose de experiências, a qual sua infinita sabedoria do "mundo" tinha como garantir para ela. Se tivessem podido utilizar uma alavanca para forçar a abertura de sua alma e entupi-la de "mundo", teriam, sem dúvida, feito, sem sequer observar a morte de sua paciente na 
mesa de cirurgia. A garotinha gritava e chacoalhava, tapando as orelhas com os braços para amortecer o barulho e despegando os olhos para ocultar o bombardeio da detonação visual. Observava aquelas pessoas, ansiando que conhecessem também elas o inferno do sentidos. Observava a tortura de uma vítima que não podia se defender numa linguagem compreensível. [....] Esses cirurgiões operavam com ferramentas de jardineiro, e sem anestesia. (WILLIAMS, 1996, p. 38-9)

A idéia maior do método Lovaas é a de promover uma reeducação sensorial precoce, de preferência a partir dos trinta meses - ela só seria realmente eficaz na razão de quarenta horas de estímulo por semana; e isso durante dois anos. A principal explicação dos fracassos por parte de seus partidários seria a dificuldade de se mobilizar a longo prazo durante um período como esse! É bom para os autistas que ele seja praticamente inaplicável em todo o seu rigor. ${ }^{26}$

Quando Sacks visita os EUA nos anos de 1990, uma casa especializada na educação de autistas - só que mais inspirada pelo método Teacch - constata que muitos aprenderam a funcionar tanto bem, quanto mal. Não pôde, contudo, renunciar a um certo mal-estar:

é certo que muitos deles tinham aprendido a "operar" a partir de um modo, a mostrar pelo menos um reconhecimento formal e externo das convenções sociais - e, contudo, a própria formalidade ou exterioridade de seus comportamentos era em si desconcertante. Senti isso especialmente em uma escola que visitei, onde as crianças esticavam as mãos duras e diziam com uma voz alta e não modulada: "Bom dia meu nome é Peter... Estou muito bem obrigado como vai você", sem qualquer pontuação ou entonação, sentimento ou tom, numa espécie de litania. Será que alguma delas, perguntei-me, conseguirá alcançar algum dia uma verdadeira autonomia? (SACKS, 1997, p.260) ${ }^{27}$.

Quando o sujeito autista não se encontra em condições de fazer escolhas, quando seus familiares não procederam a um reforço educativo, então, no limite superior do espectro do autismo, o duplo desvanece e o objeto autístico ganha uma função social. Subsiste, contudo, certo estilo da relação com o Outro sempre mediada pelo duplo ou pelo objeto - ela orienta o sujeito rumo a uma relação fusional-dependente com um parceiro.

Mesmo entre os autistas de alto funcionamento, muitos permanecem dependentes de um parente. Outros chegam a deixar o nicho familiar, mas, como Sean Barron, telefonam diversas vezes por semana para um parente, para o qual tudo se pode dizer e que ajuda na tomada de decisões. Outros, ainda, estabelecem uma relação privilegiada com um parceiro, vivem em casal - hétero ou homossexual -, estreitamente dependentes um do outro; em especial, o que é o caso freqüente, quando todos os dois são autistas. O duplo autístico é uma proteção contra o Outro, bem mais que um perseguidor, de tal modo que, apesar da relação em espelho que os une, os casais de autistas mostram-se mais estáveis que conflituosos.

Muitos autistas poderiam, sem dúvida, dizer como Sellin (1998, p.181) — "Eu me esforço em, por mim mesma, fazer de tudo para encontrar uma salvação [salut]" ou, como Joey, a criança-máquina de Bettelheim - "eu mesmo me botei" -, sem passar pelo Outro, sempre sem alienação, nem separação. Concebe-se que o tratamento analítico tropeça, aí, numa dificuldade, e a raridade das demandas feitas pelos sujeitos autistas em seu nome próprio é testemunha. É-lhes difícil aceitar um objeto de gozo vindo do mundo exterior e não oriundo de seu mundo seguro - ainda que aberturas 
sejam possíveis passando pelo duplo, pelo objeto autístico, e sabendo tratar o Outro de síntese. Não é disso que Asperger tinha a intuição quando aconselhava que falassem com eles com "uma paixão desbotada", isto é, tomando emprestada uma enunciação semelhante à sua? Fazer semblante de objeto autístico implica não ocupar-se demais com eles, mas possibilitar que se façam escutar: é uma condição que lhes favorece encontrar apoio próprio para animar sua dinâmica subjetiva.

\begin{abstract}
In order to construct him/herself, the autistic subject who refuses to become alienated, is confronted with the difficulty which only belongs to their subjective structure: how to treat the pleasure of living when they do not have the wherewith to mortify it which meaning constitutes? In this regard, the rare witness of high functioning autistic subjects who became involved in individual treatment teaches one a lot. They can be seen as a type of laboratory study of their subjective functioning. It is generally thought that in their rearing their needs should be pandered to. However, there is no educational practice which contemplates the option of having more or less explicit recourse to the use of the binary reward-punishment. That the autistic person knows about this duality is an assumption that is not questioned by those who set aside the theory of the subject.
\end{abstract}

Key-words: Autism. Alienation. Witness. Educational practices.

\footnotetext{
NOTAS

${ }^{1}$ Psicóloga clínica com mais de quarenta anos de experiência em distúrbios infantis, Mira Rothenberg é co-fundadora e diretora do Blueberry Treatment Centers, Inc. - a primeira agência terapêutica reconhecida internacionalmente para o tratamento de crianças autistas e esquizofrênicas - e autora de Children with emerald eyes: histories of extraordinary boys and girls (North Atlantic Books, 1960/2003). [N. do T.]

${ }^{2}$ Sean Barron, junto de sua mãe, Judy Barron, relata suas experiências com o autismo no livro There's a boy in here (Chapmans, 1993). [N. do T.]

3 Temple Grandin (1947- ) é Doutora em Ciência Animal pela Universidade Estadual do Colorado, autora best-selling e consultora em comportamento animal para criadores (teoriza, entre outras, sobre questões envolvendo o confinamento animal e seu bem-estar; cf. $\underline{\text { www.grandin.com}})$. Autista de alto funcionamento, Grandin é também muito conhecida por seu trabalho em advogar a favor do direito dos autistas. [N. do T.]

${ }^{4}$ Birger Sellin (1973- ) foi o primeiro autista a tornar-se um autor publicado na Alemanha. Seu primeiro trabalho, intitulado Ich will kein Inmich mehr sein - Botschaften aus einem autistischen Kerker [Não quero mais estar em mim: mensagens de uma mente autística], era constituído basicamente por poemas. [N. do T.]

${ }^{5}$ Conforme Di Ciaccia (2005, p. 12), a expressão foi nomeada por Miller, em 1992, para referir-se a uma prática utilizada por uma instituição que se ocupava de casos de autismo e psicose em crianças e adolescentes. As condições para essa prática, segundo o autor, são estruturadas a partir dos seguintes eixos: a parceria de cada membro da equipe com a criança; a reunião de equipe; a função do diretor terapêutico e a referência teórico-clínica. [N. do T.]

6 A tese de Tustin (1992, p.41), segundo a qual as defesas autísticas visam a proteger da experiência traumática do "buraco negro" - que Williams chama de "Grande Nada Negro" -, associada à sensação de ter perdido uma parte vital de seu próprio corpo, ou do corpo da mãe, constitui outra abordagem imaginária do mesmo fenômeno. A perda primordial do objeto de gozo é vivida pelo sujeito autista como
} 
um dilaceramento não-simbolizável. A cisão entre os afetos e o pensamento protege de toda e qualquer apreensão de gozo.

${ }^{7}$ É o que confirma um autista de alto funcionamento como Dibs, quando declara à sua terapeuta, dois anos e meio depois do fim de seu tratamento, "descobri que não sou infeliz quando sinto o amor." (DIBS, 1967, p.239)

${ }^{8}$ Williams sublinha, ela própria, o verbo 'existir' e a palavra 'subjetividade'.

${ }^{9}$ Referência utilizada por Jacques Lacan, o nó borromeano constitui três círculos atados de forma que um corte em qualquer um deles desfaz os outros dois. [N. do T.]

${ }^{10}$ Uma das funções da borda é a de "marcar uma pulsação regrada" do gozo do outro. (LAURENT, 1997, p.42)

${ }^{11}$ Quando introduz essa fórmula, em 1992, E. Laurent dá como exemplo da borda a "carapaça" de Tustin; isto é, objetos autísticos protetores cuja dimensão de duplo é particularmente acentuada. Nós alargaremos um pouco mais o conceito de borda autística, incluindo nele outro elemento: o ponto de competência, fonte do Outro de síntese, que participa tão regularmente quanto o duplo e o objeto na localização do gozo do sujeito, se levamos em conta as formas evolutivas do autismo infantil precoce. A freqüente interpenetração desses três elementos justifica, além disso, reagrupá-los sob o conceito de borda autística (LAURENT, 1992, p.156).

12 «Cherche à me reconnaître dans le miroir exaspérant / la securité / veux me regarder / mais n'ose pas / j'y vois toutes les peurs de l'autisme / celui qui démolit volontairement les choses »

${ }^{13}$ Carol foi construída quando ela tinha quatro anos e meio. É, pois, mais ou menos entre cinco e nove anos que Williams tenta entrar no espelho.

${ }^{14}$ Ela, aqui, designa o próprio reflexo de Williams. [N. do T.]

${ }^{15}$ A escrita nasceu de símbolos representando imagens de objetos, e é ao se estilizarem que são afastados da representação para se tornarem, nas escritas alfabéticas, letras que notam os sons da língua. (GELB, 1952/1973)

${ }^{16}$ Inicialmente Willie «não era nada além de um par de olhos verdes brilhando na escuridão». (WILLIAMS, 1992, p. 29)

${ }^{17}$ Esse aparelho desenvolvido por Grandin é uma espécie de brete para gado - baia estreita utilizada para ter um determinado controle sobre a mobilidade do animal -, com dispositivos que se moldam em função do formato do corpo e que impedem o seu movimento. [N. do T.]

${ }^{18} \mathrm{Na}$ versão francesa, citada por J.-C. Maleval, comparece a expressão «rumo ao mundo real». [N. do T.]

${ }^{19}$ Tradução ligeiramente modificada

${ }^{20}$ Evangelho de São João (10:7.9). [N. do T.]

${ }^{21}$ Gilles Tréhin (1972- ) é um autista de alto funcionamento que vive em Cagnes sur Mer, no sudeste da França. Artista e autor, seu livro - que também leva o título de Urville - é baseado nos escritos ficcionais sobre os dados da cidade. [N. do T.]

${ }^{22}$ Alguns dos mais de 300 desenhos de diferentes partes de Urville, todos feitos por Tréhin, podem ser apreciados em www.urville.com. [N. do T.]

${ }^{23}$ Atwood (2003, p.129) constata que os sujeitos que apresentam a síndrome de Asperger, meninos ou meninas, são vulneráveis às agressões sexuais - o que Williams confirma -, ao passo que não encontrou "qualquer agressor entre eles".

${ }^{24}$ Inventado pelo Dr. O. Ivar Lovaas, psicólogo na Universidade da Califórnia, Los Angeles, esse método necessita de um acompanhamento diário do comportamento da criança autista. Originalmente - tipo de punição abolido no fim da década de 80 - os terapeutas batiam nas coxas das crianças quando elas não se comportavam conforme o esperado (cf. www.lovaas.com). [N. do T.]

${ }^{25}$ Treatment and Education of Autistic and Related Communication Handicapped Children [Tratamento e Educação de Crianças com Autismo e Deficiências de Comunicação Relacionadas), o método Teacch foi estabelecido no início da década de 1970 por Eric Schopler, e se trata de um programa de tratamento utilizado inicialmente no estado da Carolina do Norte. Emprega técnicas que se valem das habilidades visuais para que as crianças mantenham a atenção e, então, interajam com outras crianças (cf. www.teacch.com). [N. do T.]

${ }^{26}$ No ano de 1987, Lovaas apresentou um trabalho pelo qual mostrava que nove das 19 crianças, depois de ao menos dois anos de submissão às quarenta horas semanais de seu tratamento, foram classificadas como de desempenho normal - o que contrapunha os meros $2 \%$ das crianças de um outro grupo que, segundo ele, receberam uma versão menos intensiva. Em 2000, porém, um grupo de pesquisadores treinados por Lovaas tentou, em vão, corroborar suas descobertas - ao que ele respondeu com o 
argumento de que tais estudiosos provavelmente não teriam trabalhado de forma tão eficiente quanto ele e seu grupo de pesquisas o haviam feito. [N. do T.]

27 tradução ligeiramente modificada

\section{REFERENCIAS}

ASPERGER, H. [1944]. Les psychopathes autistiques pendant l'enfance. Les empêcheurs de tourner en rond. Paris : Synthélabo. Le Plessis-Robison. 1998.

ATWOOD, T.[1999]. Le syndrome d'Asperger et l'autisme de haut niveau. Paris: Dunot, 2003.

BARRON, J.; BARRON, S. [1992]. Moi, l'enfant autiste. Paris: Plon, 1993.

BERQUEZ, G. L'autisme infantile. Paris: PUF, 1983

DIBS, V. A. [1964]. Développement de la personnalité grace à la thérapie par le jeu. Paris: Flammarion, 1967.

DI CIACCIA, A. La pratique à plusieurs. La cause freudienne. Paris: Navarin, 2005.

EHLERS, S.; GILLBERG, C.. The epidemiology of Asperger syndrome. A total population study. In: Journal child psychology and psychiatry, 34, 8; p. 1327-50, 1993.

FOMBONNE, E. e TIDMARSH, L. Epidemiologic data on Asperger disorder. In: Child and adolescent psychiatric clinic of North America, 12, 1, pp. 15-21, 2003.

GELB, I. J. [1952]. Pour une théorie de l'écriture. Paris: Flammarion, 1973.

GRANDIN, T. [1983]. Uma menina estranha: autobiografia de uma autista. São Paulo: Cia. das Letras, 1999. [1995] Penser en images. Paris: O. Jacob, 1997.

HEMSLEY, R. et al. [1978] Le traitement des enfants autistes dans environnement familial. In: RUTTER, Michael e SCHOPLER, Eric. L'autisme. Une réévaluation $d u$ concept et des traitements. Paris: PUF, 1991.

KANNER, L. Autistic disturbances of affective contact. In: Nervous child, 1942-1943, 3, 2, p. 217-230..

KANNER, L.; RODRIGUEZ, A.; ASHENDEN, B. How far can autistic children in matters of social adaptation? In: Journal of autism and childhood schizophrenia, 1972, 2,$1 ;$ p. 9-33.

LACAN, J. [1958]. Observação sobre o relatório de Daniel Lagache. In: Escritos. Rio de Janeiro: Jorge Zahar, 1998; pp. 653-91. 
. [1975]. Conférence à Genève sur le symptôme. Le bloc-notes de la psychanalyse. Genebra, nº 5, 1985.

L’acte psychanalytique. Seminário inédito, 1967-68.

LAURENT, E.. Discussion. In L'autisme et la psychanalyse. Presses Universitaires du Mirail, 1992.

. Réflexions sur l'autisme. In Bulletin groupe petite enfance, 1997.

LEFORT, R.; LEFORT, R.. Naissance de l'Autre. Paris: Seuil, 1980.

Sur l'autisme. Travaux et recherches en cours. Entretien avec F. Ansermet. In:

L'enfant «prêt-à-poser. Paris. Agalma, 1998 p. 37.

LEMAY, M. L'autisme aujourd'hui. Paris: O. Jacob, 2004.

MORAR, T. Ma victoire sur l'autisme. Paris: O. Jacob, 2004.

NAZEER, K. Laissez entrer les idiotes. Paris: Oh Editions, 2006.

PARK, C. C.. [1967] Histoire d'Elly. Le siège. Paris: Calman-Lévy, 1972.

ROTHENBERG, M. Des enfants au regard de pierre. Paris: Seuil, 1979

SACKS , O. [1995] Um antropólogo em marte. São Paulo: Companhia das Letras, 1997.

SCHOPLER, E.; REICHLER, R.; LANSING, Margaret. Stratégie éducatives de l'autisme. Paris: Masson, 2002.

SELLIN, B. [1993] Une âme prisionnière. Paris: Robert Laffont, 1994. [1995]. La solitude du déserteur. Paris: R. Laffont, 1998.

TRÉHIN, G. Urville. Chatou: Carnot, 2004.

TUSTIN, F. Autisme et protection. Paris: Seuil, 1992

WILLIAMS, D. Si on me touche, je n'existe plus. Paris: Robert Laffont, 1992. [1994] Quelqu'un, quelque part. Paris: J'ai lu. 1996. 
Jean-Claude Maleval é psicanalista, membro da Escola da Causa Freudiana e da Associação Mundial de Psicanálise, professor de psicopatologia na Universidade Rennes II e autor de Folies hystériques et psychoses dissociatives (1991), La logique du délire (1997), e La forclusion du nom-du-père (2000).

Paulo Sérgio Souza Jr. é mestrando em Linguística pelo IEL - Unicamp e, atualmente, professor-associado da Universitatea "Alexandru Ioan Cuza” (Iaşi / Romênia).

E-mail: contra_sujeito@yahoo.com.br 